\title{
Entre o conservadorismo orçamentário e o desenvolvimento regional: finanças públicas e infraestrutura de transportes em Minas Gerais na Primeira República
}

\section{Between Budgetary Conservatism and Regional Development. Public Finances and Transportation Infrastructure of Minas Gerais in the First Republic}

\author{
Marcelo Godoy, André A. Horta, Lidiany Barbosa \\ Universidade Federal de Minas Gerais, Belo Horizonte, Brasil, \\ emails: mmgodoy@cedeplar.ufmg.br; andrehortap@gmail.com; lidiany@cedeplar.ufmg.br
}

\begin{abstract}
Resumo: O principal escopo é examinar, com base em novas evidências, a evolução das finanças públicas de Minas Gerais na República Velha, com destaque para o lugar do dispêndio com a infraestrutura de transportes. Também se discute a vigência de conflito entre preocupação com o equilíbrio orçamentário e políticas de desenvolvimento. Na primeira seção são analisadas as receitas e despesas estaduais, com ênfase na classificação dos comportamentos assumidos por essas variáveis ao longo do período e na determinação das principais rubricas que as compunham. Também é examinada a evolução da dívida fundada, assim como sua correlação com as despesas públicas. A segunda seção analisa especificamente os gastos com a infraestrutura de transportes, nomeadamente ferrovias e estradas de rodagem. Primeiro o relacionamento entre o crescimento da malha ferroviária e as despesas do Estado com garantias de juros, subvenções e empréstimos a companhias ferroviárias. Em seguida a evolução dos gastos com rodovias.
\end{abstract}

Palavras-chave: Minas Gerais; República Velha; finanças públicas; transportes; desenvolvimento regional.

Abstract: The principal scope of this study is to examine, based on new evidence, the evolution of the public finances of Minas Gerais in the Old Republic, with an emphasis on the role of transportation infrastructure expenditures. Also discussed is the conflict between concern over budgetary equilibrium and development policies. The first section analyzes state revenues and expenses, with emphasis on the classification of the behaviors of these variables over the period and the determination of the main categories that make them up. Also analyzed is the evolution of government funded debt, as well as its correlation with public expenditures. The second section specifically analyzes expenses on transportation infrastructure-in this case, railroads and highways, first by examining the relationship between growth in the railway network and State 
outlays for interest guarantees, subsidies and loans to railway companies, and then the evolution of expenditures on railways.

Key words: Minas Gerais; Old Republic; public finances; transportation; regional development.

Artigo recebido: 11 de julho de 2016. Artigo aceito: 6 de setembro de 2016

Porque entendo que hoje, mais do que nunca, nós precisamos reagir, nós precisamos resistir a essa ânsia, a essa febre, a essa impaciência de progredir que se traduz num aumento excessivo de despesas, que se caracteriza por uma generalizada mania de grandezas, por uma verdadeira doença que vem se alastrando, de certo tempo a esta parte, por todo o Brasil; porque sem uma certa resistência pode resultar uma tal ou qual desproporção, um desequilíbrio funestíssimo entre o nosso desenvolvimento efetivo e real e os órgãos, o arcabouço, os aparelhos que a nossa fantasia lhe venha criar [...] Eis aí o problema da viação, de cuja solução pendem os interesses fundamentais do estado ou, antes, do Brasil, porque se há uma verdade consagrada pela prática, se há uma verdade sufragada pela observação de todos os dias é esta: o problema do estado de Minas, o problema do Brasil é antes de tudo, é acima de tudo, é exclusivamente, um problema de estradas. Estradas de ferro, estradas de rodagem, estradas eletrificadas, que valorizem a terra e o trabalho, aproximando a produção dos mercados de consumo, eis aí a chave do nosso desenvolvimento econômico, sem o qual não pode haver progresso (Deputado Raul Soares no Congresso do Estado de Minas Gerais. Fundação João Pinheiro, 2006, pp. 126 e 128).

\section{INTRODUÇÃO}

4 m discurso proferido no Congresso Mineiro em 1911, quando o então deputado estadual Raul Soares criticou a proposta de orçamento em debate, estavam presentes de forma clara os termos de conflito que parece ter permeado a compreensão da relação entre finanças públicas e políticas de desenvolvimento em Minas Gerais durante a República Velha. Nos excertos em epígrafe, buscou-se assinalar a presença de uma tomada de consciência quanto ao imperativo do equilíbrio na condução do gasto público, ante as limitações de recursos orçamentários, e, ao mes- 
mo tempo, atender ao ditame do enfrentamento de gargalo infraestrutural como requerimento para o desenvolvimento. O paradoxo é evidente, posto que se almejava operar com prudência e realismo financeiro, bem como ancorado nos limites do desenvolvimento possível, e, concomitantemente, se reconhecia a necessidade do arrojo ante os pesados investimentos em transportes imprescindíveis ao desenvolvimento econômico.

O principal escopo do artigo é examinar, com base em novas evidências, a evolução das finanças públicas de Minas Gerais na República Velha, com destaque para o lugar do dispêndio com a infraestrutura de transportes. Também se discute, por meio de exaustivo exame das contas públicas, a vigência de conflito entre preocupação com o equilíbrio orçamentário e políticas de desenvolvimento. Os dados compendiados e sistematizados permitem compor quadro comparativo da evolução das finanças públicas de Minas Gerais a contemplar o período provincial (Mendes, 2007; Barbosa, Godoy e Mendes, 2011) e a Primeira República. Trata-se do cotejo de dados que cobrem quase 100 anos de história financeira de Minas Gerais ${ }^{1}$ e facultam avaliar a participação dos gastos com a infraestrutura de transportes durante quase toda a era ferroviária mineira (1870-1940). ${ }^{2}$

O estudo das finanças públicas do estado de Minas Gerais na Primeira República ainda desperta pouco interesse historiográfico, dada a exiguidade de pesquisas sobre o tema. ${ }^{3}$ Notável exceção é John Wirth (1982, pp. 281-305), em O fiel da balança, Minas Gerais na federação brasileira, 18891937, que incluiu estudo do federalismo fiscal mineiro na República Velha e início da era Vargas.

Outra relevante exceção é Política econômica do Estado de Minas Gerais, 1890-1930. O autor (Iglésias, 1982, pp. 115-144) observou que os valores da receita e da despesa tendiam a se equilibrar no orçamento, prevalecendo apenas leve vantagem por parte da receita. No que diz respeito aos valores executados, estes costumavam superar enormemente os orçados. Em se tratando da visão que os governantes tinham das finanças, o autor afirmou a falta de dinamismo da administração republicana até 1930, que

\footnotetext{
${ }^{1}$ Bastos (1997) e Bessa (1981), duas das principais referências para a história financeira de Minas Gerais, não contemplaram sistematicamente a evolução das finanças públicas com base nas fontes primárias que compõem o corpus documental da presente pesquisa sobre o período da República Velha, que são as mesmas fontes da investigação histórica congênere para o período provincial (Mendes, 2007; Barbosa, Godoy e Mendes, 2011).

${ }^{2}$ Para apreciação geral da era ferroviária mineira, e que abarque o conjunto do território de Minas e abranja todo o período da primeira modernização dos transportes, ver Batista, Barbosa e Godoy (2012).

${ }^{3} \mathrm{O}$ quadro não deve ser diferente para os outros estados brasileiros: "Uma pesquisa que dê conta da evolução das finanças estaduais durante a República Velha ainda está por ser feita e conta com grande dificuldade no levantamento e compatibilização dos dados” (Costa, 1998, p. 167).
} 
não só investia valores mínimos e procurava gastar tão pouco quanto fosse possível, como também evitava ao máximo tomar empréstimos, fossem eles internos ou externos. Ainda segundo Iglésias (1982), Minas Gerais era uma das unidades da dederação que mais tendia ao equilíbrio orçamentário, meta que os governos teriam priorizado ante as exigências do desenvolvimento econômico. ${ }^{4}$

As principais fontes primárias compulsadas foram os relatórios dos presidentes de Estado e a legislação estadual, especialmente as leis orçamentárias. Os relatórios contemplaram as matrizes teóricas que orientavam a política econômica adotada pelos governantes mineiros da República Velha, bem como assinalaram os fenômenos que incidiam sobre as finanças do Estado e que eram considerados prioritários pelos presidentes. São informações predominantemente subjetivas, mas que muito esclarecem sobre as motivações que presidiram algumas práticas financeiras recorrentes. Ainda se encontram importantes dados estatísticos nos relatórios, referentes não só aos orçamentos e à sua execução, como também sobre a dívida pública e o setor de infraestrutura de transportes, especialmente sobre ferrovias. Na legislação estadual estão disponíveis os orçamentos detalhados em rubricas, o que permite o estudo da estrutura das contas públicas.

$\mathrm{Na}$ primeira seção do artigo são analisadas, em seis tópicos, as receitas e despesas estaduais, com ênfase na classificação dos comportamentos assumidos por essas variáveis ao longo do período e na determinação das principais rubricas que as compunham. Também é examinada a evolução da dívida fundada, assim como sua correlação com as despesas públicas. São utilizados dados relativos ao orçamento e execução orçamentária. A segunda seção analisa especificamente os gastos com a infraestrutura de transportes, nomeadamente ferrovias e estradas de rodagem. Primeiro o relacionamento entre o crescimento da malha ferroviária e as despesas do Estado com garantias de juros, subvenções e empréstimos a companhias ferroviárias. Em seguida a evolução dos gastos com rodovias. A terceira seção é dedicada a síntese dos resultados.

\section{FinanÇas públicas de Minas Gerais na Primeira República}

Os Relatórios de Presidentes de Estado examinados subdividiram tanto as receitas quanto as despesas em ordinárias e extraordinárias, provavel-

\footnotetext{
${ }^{4}$ A avaliação de Wirth (1982, pp. 281-282) é semelhante, conquanto com acento em restrições orçamentárias: "Por causa dessa base tributária vulnerável e limitada, o conservadorismo fiscal do estado era algo mais do que um famoso traço da cultura”.
} 
mente como decorrência de dificuldades administrativas e contábeis que impediam a realização de projeções mais seguras. Afinal, são muitas as evidências de sérios problemas enfrentados pela administração pública para a obtenção de dados estatísticos sólidos e consistentes que pudessem fundamentar tais projeções.

O exame das diversas propostas orçamentárias permite supor que o critério para elaboração do orçamento partia da fixação das despesas ordinárias, para somente então se estimar as receitas ordinárias. As indicações são de que a projeção das despesas e receitas ordinárias era calculada basicamente sobre a observação da evolução financeira recente, considerada alguma possível alteração de legislação pertinente à arrecadação. Os eventuais desequilíbrios eram compensados com as receitas extraordinárias, as quais, porém, nem sempre se concretizavam, resultando em déficits orçamentários. As rubricas que se encaixavam nessa categoria previam receitas que poderiam vir a ocorrer no decurso do exercício fiscal, tais como empréstimos, operações de crédito, alienações patrimoniais, entre outras. Com base nessa estimativa de receitas extraordinárias, projetavam-se as despesas extraordinárias, as quais viriam a cobrir, em diversas conjunturas, os programas de investimentos, inversões financeiras e até mesmo o serviço da dívida.

$\mathrm{Na}$ execução orçamentária, tanto as receitas extraordinárias quanto as despesas extraordinárias geralmente excediam em muito o valor das receitas e despesas ordinárias. Além do mais, os dados extraídos dos relatórios poderiam ser provisórios, visto que, face às grandes dificuldades de circulação internas a Minas Gerais, nem sempre estavam integralmente disponíveis as informações tributárias necessárias ao fechamento da prestação de contas no prazo para seu encaminhamento ao poder legislativo.

A coleta dos dados obedeceu ao seguinte procedimento, em duas etapas e em duas fontes: $:^{5}$ a) foram consolidadas as informações para receitas e despesas recolhidas nos relatórios governamentais; $b$ ) também se tomou por base de dados estudo realizado pela Secretaria de Finanças de Minas

\footnotetext{
${ }^{5}$ Diante das dificuldades em se adotar indexador(es) seguro(s) para atualizar e uniformizar valores, válido(s) para o longo recorte de tempo examinado, fez se opção por não considerar a inflação do período, com a manutenção dos valores correntes na unidade monetária da Primeira República. Realizado estudo preliminar, especificamente dos valores do Índice do Custo de Vida do Brasil (Ónody, 1960, p. 25), verificou-se a presença de inflação em quase todos os anos da segunda metade da República Velha (foram apresentados dados apenas para dois anos da primeira metade do período). Divididos os valores nominais das receitas e despesas para esses anos pelos Índices de Custo de Vida correspondentes, com o objetivo de tentar captar o efeito da inflação sobre os preços e acompanhar o comportamento dos valores resultantes ao longo do tempo, constatou-se que estes valores não implicavam em alterações substantivas nos padrões evolutivos no tempo. Em suma, não há indícios de que a incorporação da inflação aos dados monetários proporcione alterações significativas nas tendências que eles evidenciam para o período. São estas tendências que importam ao estudo de caráter longitudinal que se propõe.
} 
Gerais e publicado em $1954 .{ }^{6} \mathrm{O}$ desempenho orçamentário no período pode ser visualmente examinado nos gráficos 1 e 1.A. e nos gráficos 1.B e 1.C.

O sinal do resultado orçamentário divergiu entre as duas fontes em doze dos quarenta anos analisados $(1895,1896,1897,1898,1899,1900$, 1901, 1905, 1906, 1908, 1912 e 1921), com clara tendência de maior convergência na segunda metade do período (1910-1930). Por decorrência, o mesmo pode ser inferido se comparada a forma assumida pelo gráfico $1 \mathrm{com}$ a do gráfico 1.B e a forma do gráfico 1.A com a do gráfico 1.C. O resultado obtido é similar quando comparadas às magnitudes relativas atribuídas por cada fonte ao resultado orçamentário de cada ano, sinalizadas pela razão -na forma de percentagem- entre o resultado orçamentário e a receita efetivada (ver gráfico 1.D.).

Novamente, o comportamento da representação dos dados das duas fontes tende a convergência na segunda metade do período, inclusive com marcante coincidência de valores na última década da República Velha. Mesmo nos primeiros anos do século Xx, é possível perceber, salvo algumas exceções, que os sinais das variações sofridas pela variável tendem a ser os mesmos para os dados das duas fontes, não obstante as diferenças de magnitude dessas variações.

As evidências sugerem dificuldades para o fechamento completo das contas dentro de prazo a permitir sua devida inclusão nos relatórios dos presidentes de Estado, a determinar o caráter provisório dos dados para alguns anos. Assim, optou-se por privilegiar, pelo menos parcialmente, o relatório da Secretaria das Finanças de 1954, posto que provavelmente apresente dados consolidados.

\section{Quadro geral da receita e da despesa}

Os gráficos 1 a 1.C salientam que, na República Velha, as receitas arrecadadas e as despesas realizadas apresentaram comportamento ascendente, dando continuidade à tendência observada para o período imperial.

Embora a tendência ao crescimento da receita e da despesa se manifestasse desde meados do império, ambas as variáveis, pelo menos em termos de valores absolutos, sofreram salto expressivo após a proclamação

\footnotetext{
${ }^{6}$ Os dados constantes em Minas Gerais (1954) foram discriminados como se referentes ao padrão monetário vigente desde 1942 (cruzeiros). No entanto, constatou-se que, ao menos para o período anterior a 1930, foram lançados valores em réis, segundo a confrontação com os respectivos dados recolhidos nos Relatórios de Presidentes de Estado. A publicação da Secretaria das Finanças do governo Juscelino Kubitschek, então presidida por Odilon Behrens, não relaciona as fontes dos dados compendiados.
} 


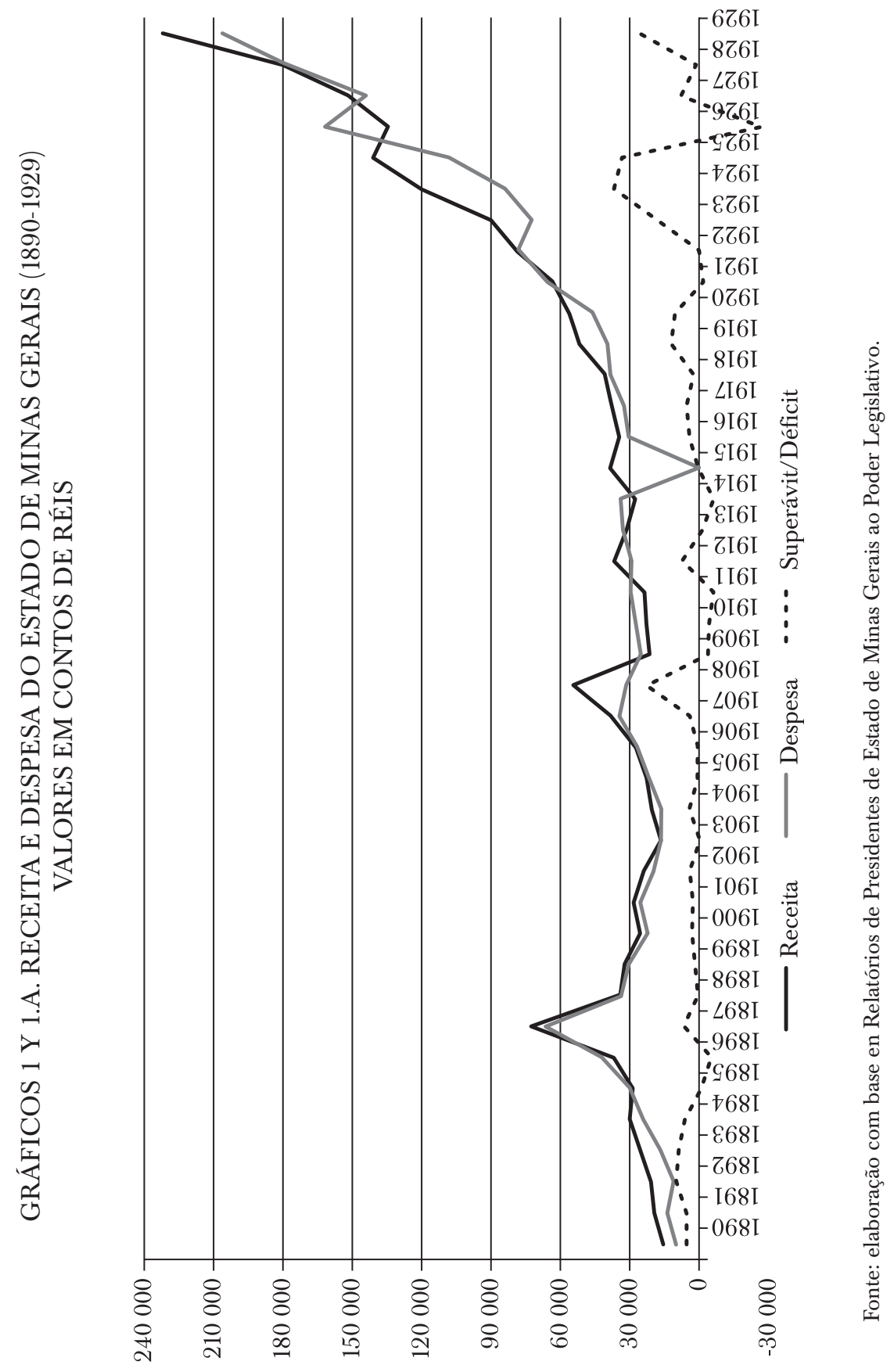




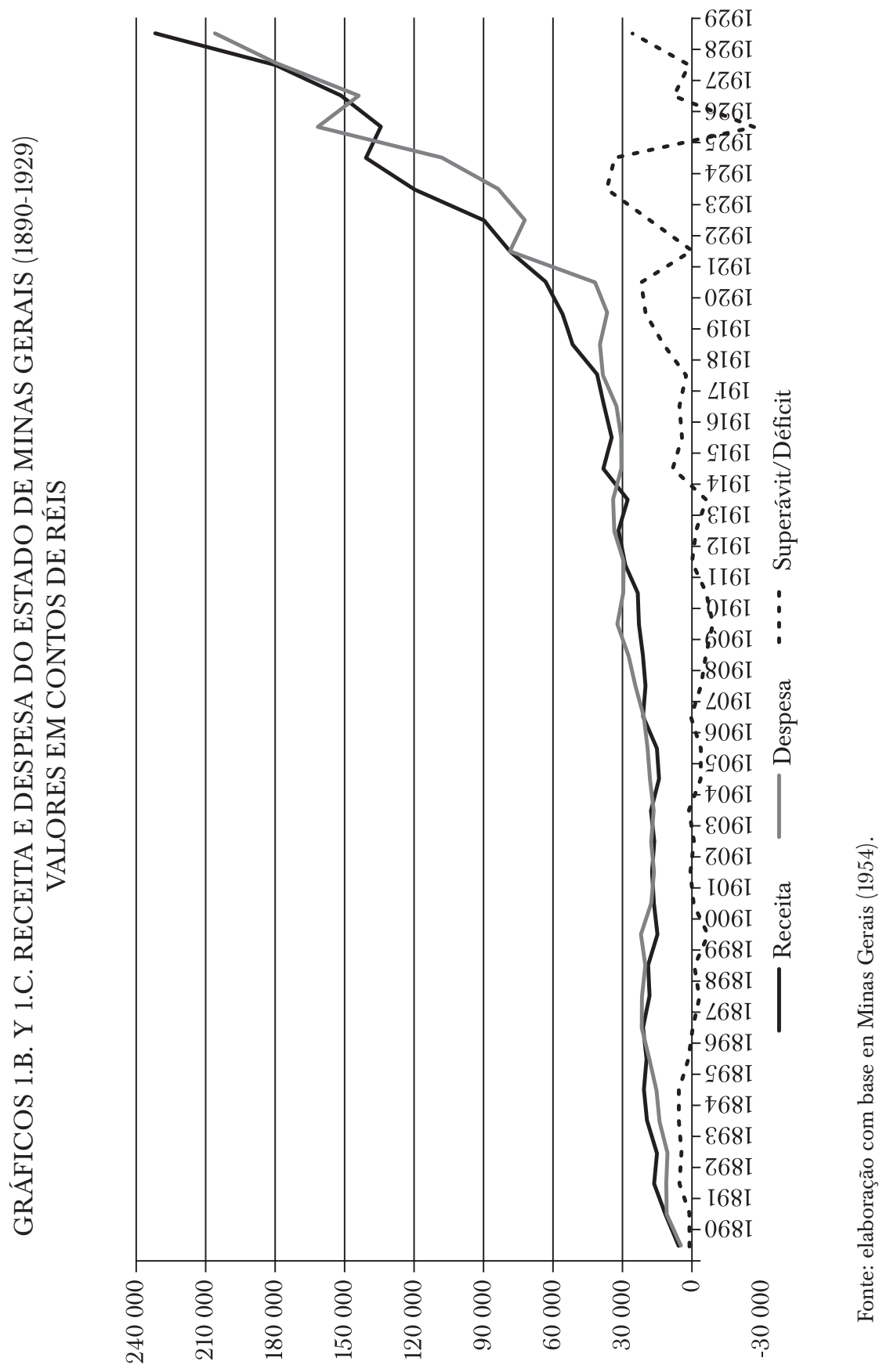




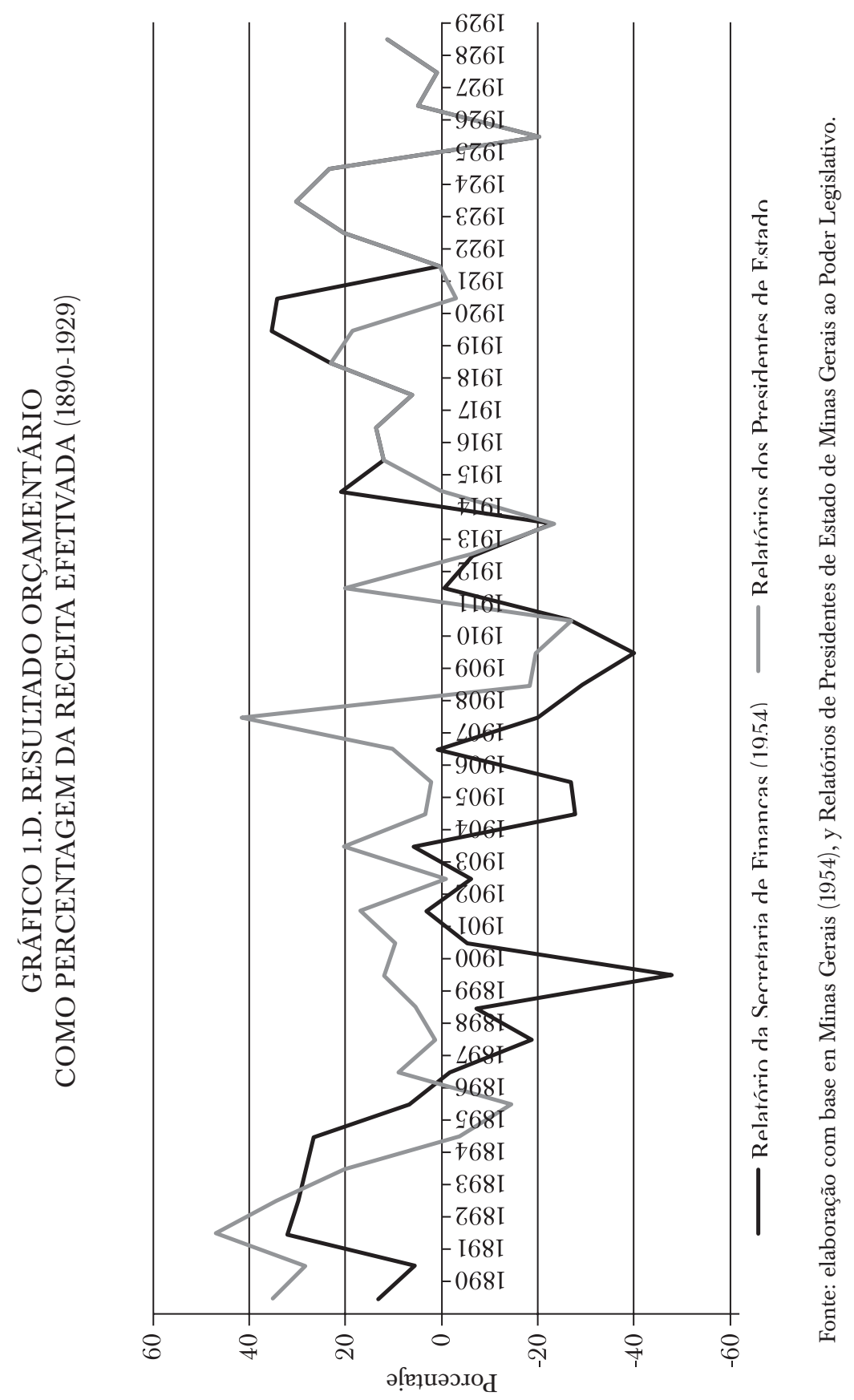


da república, e muito além de qualquer inflexão na evolução da inflação. Segundo dados apresentados por Mendes (2007, p. 32), a receita anual realizada pela província, mesmo nos últimos anos do período imperial, alcançou pouco mais de 4000 contos de réis. Na república, a receita executada superou os 15000 contos de réis ainda em 1890 (ver gráfico 1). Do mesmo modo, durante o império, a despesa anual jamais atingiu os 4000 contos de réis (Mendes, 2007, p. 36), enquanto que, em 1890, seu valor superou os 10000 contos de réis (ver gráfico 1). Provavelmente, em alterações da estrutura tributária -em especial a nova divisão de competências entre os governos estaduais, municipais e o governo central, decorrente do pacto federativo que definiu acentuada descentralização política e administrativa entre o império e a república (Resende, 2003, pp. 93-94)- esteja à explicação para a forte elevação da arrecadação do governo de Minas Gerais. ${ }^{7} \mathrm{O}$ crescimento da receita estava relacionado, no específico, ao Decreto 82, de 24 de maio de 1890 (Bessa, 1981, pp. 146-147), que simplificou e facilitou a coleta de impostos de exportação, bem como, no geral, à maior autonomia arrecadatória conferida aos estados pela Constituição de 1891 (Bessa, 1981, pp. 145-150). Com o aumento da receita, a despesa foi ampliada proporcionalmente. ${ }^{8}$

Segundo a historiografia da Primeira República, parte significativa desse crescimento das receitas e despesas deve ser atribuída à expansão econômica de Minas Gerais, particularmente do setor exportador, com grande destaque para a cafeicultura. John Wirth (1982, p. 76) afirmou que o valor per capita das exportações mineiras, em mil-réis de 1912, cresceu quase 200\% na República Velha, tendo passado de $29 \$ 300$ em 1890 para $76 \$ 200$ em 1930. No mesmo sentido, dados apresentados por Martins Filho $(2009$, p. 51) sobre o valor real do total das exportações, em contos de

\footnotetext{
${ }^{7}$ A comparação da evolução do crescimento das receitas do governo da União e do Estado de Minas Gerais demonstra tendência de longo prazo de maior expansão da arrecadação mineira. Na década de 1900 , a receita da União cresceu $70.4 \%$ e a de Minas Gerais $57.1 \%$; na década de 1910, a receita da União cresceu 75.7\% e a de Minas Gerais 145.9\%; na década de 1920, a receita da União cresceu $82.0 \%$ e a de Minas Gerais $152.2 \%$. Entre 1900 e 1930, a receita da União cresceu $544.9 \%$ e a de Minas Gerais $974.6 \%$. A expansão mais do que proporcional das receitas mineiras impulsionaram o crescimento relativo das receitas de Minas comparadas com as da União. Em 1900, Minas arrecadava 4.7\% do valor da arrecadação da União, em 1910 passou para 4.4\%, em 1920 alcançou 6.1\% e em 1930 perfazia 8.4 (Instituto Brasileiro de Geografia e Estatística [IBGE], 1941, pp. 120, 124-125).

${ }^{8}$ É na dinâmica econômica dos estados que se encontram os fatores que responderam pelo declínio, sobretudo a partir da primeira guerra, da posição relativa da receita arrecadada pelo governo da União sobre a receita total e o crescimento do percentual referente às receitas dos estados. Em 1907, a receita da União representava $65.8 \%$ da receita total e a dos estados perfazia $22.1 \%$. Ainda que com irregularidades, é inequívoca a curva declinante das receitas da União nas duas décadas seguintes, que respondia por $54.1 \%$ da receita total em 1929. Em sentido oposto, e também com flutuações, a curva das receitas dos estados é francamente ascensional, que perfaziam 31.1\% da receita total em 1929 (Costa, 1998, pp. 163-170).
} 
réis, indicam progressão de 68000 contos em 1889 para 239000 contos em 1930, crescimento de aproximadamente 250 por cento. ${ }^{9}$

Além da tendência do crescimento dos valores orçados, outra similaridade entre os períodos imperial e republicano está no fato de que as receitas e despesas orçadas em muito diferiram das executadas. Resultados que se coadunam com Iglésias (1982), que apontou a mencionada discrepância entre os valores orçados e os executados, assim como assinalou que receitas e despesas orçadas na República Velha "são quase iguais, com ligeira superioridade da receita" (p. 134). Em se tratando da execução orçamentária, os resultados divergem da avaliação de Iglésias, posto que os casos em que as receitas executadas superaram as despesas são em maior número que o caso inverso. De acordo com os Relatórios dos Presidentes de Estado, a receita só não superou a despesa em dez dos 39 exercícios (gráficos 1 e 1.A). O relatório de 1954 da Secretaria das Finanças, por sua vez, registrou 24 exercícios superavitários contra 17 exercícios deficitários (gráficos 1.B e 1.C)..$^{10}$

\section{Estrutura do orçamento da receita}

As receitas orçamentárias eram compostas de receitas ordinárias e receitas extraordinárias. As receitas ordinárias se dividiam em tributária, industrial e patrimonial, sendo, por assim dizer, as receitas próprias do Estado. As três receitas respondiam, em média, por $88 \%$ da receita geral anual. A receita tributária era originária da cobrança de impostos e taxas. Correspondia, em média anual, a $94 \%$ da receita ordinária e a $82.8 \%$ da receita geral. A receita industrial era proveniente da exploração de atividades econômicas pelo Estado, tais como ferrovias, serviços da imprensa oficial, cobrança de taxas escolares, entre outras. Era responsável, em média

${ }^{9} \mathrm{O}$ acentuado crescimento das receitas de Minas Gerais, sobretudo a partir da década de 1920, não se coaduna com generalização atribuída a todos os estados na República Velha, excetuado o Rio Grande do Sul: "Notável exceção nesse particular foi o estado do Rio Grande do Sul, o único a experimentar um aumento significativo de suas receitas durante o período" (Costa, 1998, p. 168). Segundos os dados do Repertório Estatístico do Brasil (IBGE, 1941, p. 126), entre 1897 e 1936, apenas São Paulo, Minas Gerais e Rio Grande do Sul apresentaram crescimento constante no referente à participação relativa no cômputo total da receita de todos os estados do Brasil. O repertório estatístico sistematizou a evolução para quatro intervalos de tempo (1897-1906, 19071916, 1917-1926, 1927-1936), com o seguinte resultado em termos percentuais para estes três estados: São Paulo $(29.3,30.4,34.5,37.8)$, Minas Gerais $(10.6,13.4,14.9,15.7)$ e Rio Grande de Sul $(6.3,8.0,12.5,14.4)$.

${ }^{10}$ Essa tendência de largo predomínio de exercícios superavitários em Minas Gerais diverge de observação referente ao conjunto dos estados: "Isso não impediu que seus orçamentos [da União] apresentassem déficit durante todo o período [da República Velha], o que também é verdade para estados e municípios" (Costa, 1998, p. 163). 
anual, por 3.7\% da receita ordinária e por $2.8 \%$ da receita geral. A receita patrimonial era aquela gerada pelo patrimônio público (arrendamento de terrenos e próprios do Estado, juros ativos de títulos e apólices de propriedade do Tesouro, entre outros). A ela se referiam, em média anual, $2.6 \%$ da receita ordinária e $2.4 \%$ da receita geral. Já as receitas extraordinárias poderiam, de certo modo, ser incluídas no que hoje se denominam receitas de capital, sendo constituídas de receitas de empréstimos a se confirmar, de alienações de bens móveis e imóveis cuja realização não estava ainda assegurada, de venda de terras devolutas, entre outras. Avalia-se que a inclusão de receitas extraordinárias no orçamento se destinava mais ao seu equilíbrio fiscal do que qualquer outra razão. Correspondiam, em média anual, a $12 \%$ da receita geral.

Os gráficos 2 e 2.A apresentam os dados referentes à composição em termos absolutos das rubricas da receita geral do Estado de Minas Gerais na República Velha (dados extraídos do Relatório da Secretaria de Finanças de 1954), e demonstram a predominância das receitas ordinárias na composição da arrecadação geral, ainda que em alguns exercícios fiscais a participação das receitas extraordinárias mostrou-se significativa. A evolução da participação relativa de cada componente na receita geral pode ser visualizada no gráfico 2.B.

É notável a correspondência entre a linha da receita tributária e a linha das receitas extraordinárias, que são praticamente espelhos uma da outra. Afinal, entre as receitas ordinárias, aquelas oriundas dos tributos tinham participação muito maior que as outras, superando $90 \%$ em alguns anos. Como o restante da receita geral era classificado como receitas extraordinárias, é natural que a participação desta receita crescesse (decrescesse) nos períodos de queda (elevação) da participação da receita tributária.

São destacáveis quatro picos na linha das receitas extraordinárias: a) no início do período republicano, em especial para o ano de 1891, seguido de tendência declinante até 1896, quando se abre fase de certa estabilidade a se estender até $1906 ;$ b) entre 1908 e 1910, seguido de nova fase de certa estabilidade ou crescimento não pronunciado, que se estende até $1920 ; c$ ) em 1922, apesar de inserido em tendência de crescimento desde 1921, a se estender até o final da década; $d$ ) em 1929, com inflexão no sentido de aceleração do crescimento observável para a última década da República Velha. Para o primeiro pico aventa-se à hipótese de que a mudança de regime e a reorganização político-administrativa decorrente -bem como a instabilidade econômica e a crise financeira da primeira década republicana- sejam fatores decisivos (Prado, 1959, pp. 223-227). Para os outros três picos, propõem-se como hipótese a incidência de repercussões de crises do setor cafeeiro e as políticas de valorização, associadas à queda da arrecadação originária de impostos sobre as exportações de café (Furtado, 


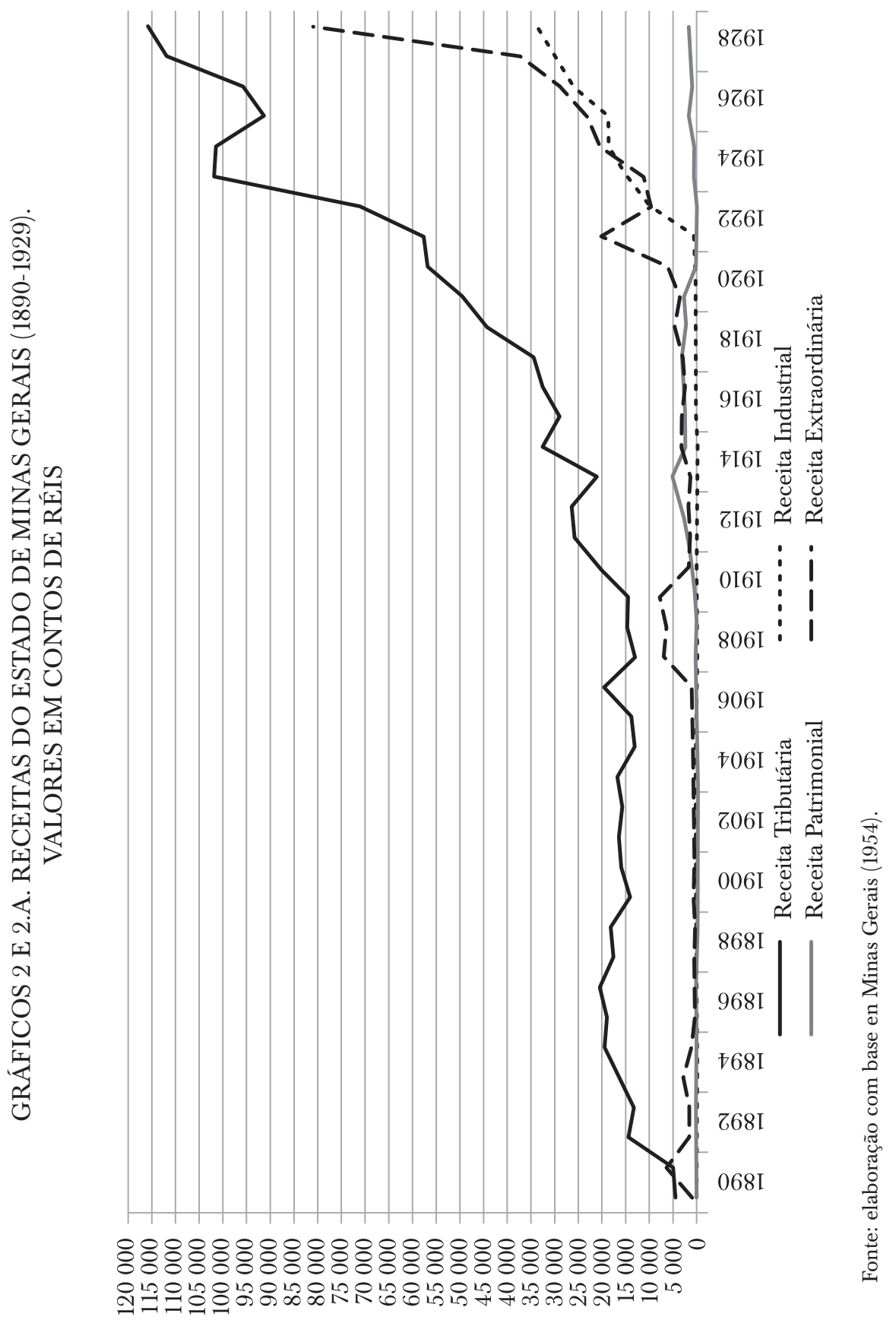




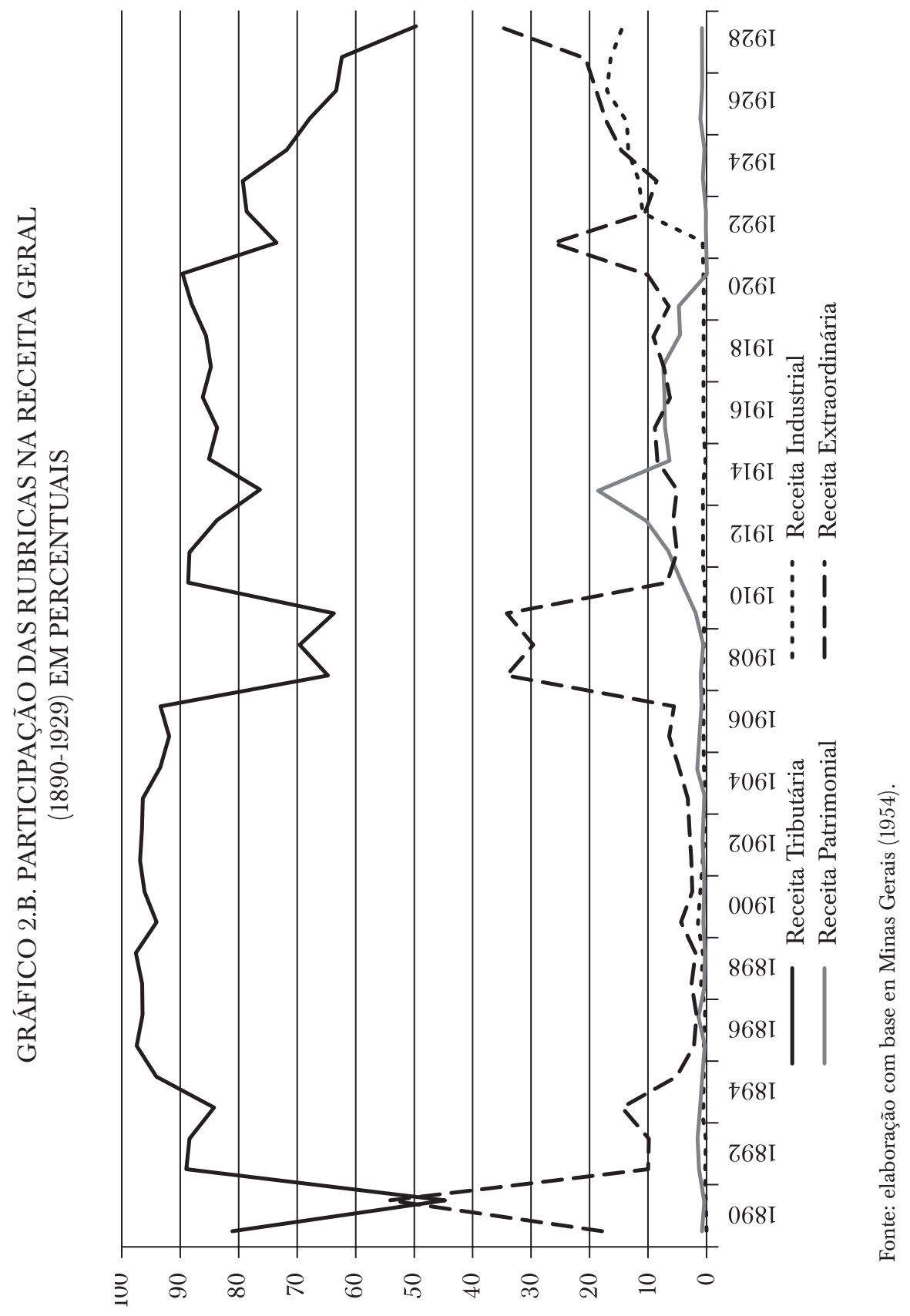


1959, pp. 207-216). O crescimento da receita industrial a partir da década de 1920 estava fortemente associado a contrato celebrado em 1921 entre a União e o governo do Estado, que assumiu a administração da ferrovia Rede Sul Mineira, cabendo ao Tesouro Estadual metade da receita líquida gerada no tráfego da empresa (Batista, Barbosa e Godoy, 2012, p. 175).

Com a finalidade de aprofundar a análise da composição das diversas receitas do Estado de Minas Gerais, são contemplados agora orçamentos da receita para anos selecionados, considerados representativos de três épocas distintas da República Velha: início da década de 1890, que se caracterizou por elevada instabilidade política e econômica (Resende, 2003, pp. 104-112; Prado, 1959, pp. 223-229); meados da Primeira República, com o sistema político oligárquico em pleno vigor e auge do modelo econômico primário exportador (Resende, 2003, pp. 112-119; Prado, 1959, pp. 231-261), e final da década de 1920, crise do liberalismo oligárquico e de sistema econômico agroexportador (Ferreira e Pinto, 2003, pp. 403411; Furtado, 1959, pp. 211-216).

A arrecadação tributária do Estado foi inicialmente definida pela Lei 16, de 19 de novembro de 1891, que além de estabelecer como competência estadual a cobrança de determinados impostos, taxas ou tarifas, dava ampla abertura para a instituição de novos tributos. Ou seja, podia se criar novos tributos pela simples inclusão na lei orçamentária, sem necessidade de nova consulta ao legislativo estadual.

O tabela 1 apresenta as receitas para o orçamento do exercício de 1893, conforme autorização contida na Lei 39, de 21 de julho de 1892 (Collecção, 1893, pp. 36-40). A previsão era de arrecadação total de nove mil e seiscentos e trinta e cinco contos e cento e sessenta mil réis. Como na estrutura de arrecadação do período imperial mineiro (Mendes, 2007, pp. 29-31), no início da República persistia em Minas Gerais o predomínio da arrecadação oriunda do comércio exterior ( $85.1 \%$ do total), em consonância com fenômeno universal nas estruturas tributárias das demais unidades regionais na Primeira República ${ }^{11}$ e a se constituir em poderoso obstáculo à integração do mercado interno nacional (Lopreato, 2002, p. 17; Costa,

${ }^{11}$ Por comércio exterior deve-se entender o intercâmbio com outros países e também com outros estados da Federação. Portanto a contemplar impostos interestaduais. Os estados que não detinham um setor de mercado externo importante "sofriam dificuldades financeiras em razão da precária arrecadação. Essas unidades, em busca de maior poder de arrecadação, utilizaram-se dos impostos interestaduais para incrementar suas receitas, tributando: $a$ ) as operações de exportação de produtos para outros Estados; $b$ ) a circulação e trânsito de mercadorias nos seus territórios. [...]. Em 1904, o Decreto-Lei 1.185 proibiu a cobrança dos impostos interestaduais, mas a base tributária estreita e a autonomia com que os Estados decidiam sobre as questões fiscais levaram o decreto a tornar-se letra morta. As receitas dos impostos interestaduais constituíam norma e representavam parcela importante da receita tributária de que os governos estaduais se valiam para atender aos gastos" (Lopreato, 2002, pp. 17-18). 
1998, pp. 167-168). A rubrica que liderava a arrecadação era o imposto sobre gêneros de exportação, que representava $74.7 \%$ da renda total estimada. Em segundo lugar estava o imposto sobre gêneros de consumo de fora do estado, que representava $10.4 \%$ do total. Somados estes dois ao recolhimento do imposto do selo (7.5\%) e do selo de heranças e legados (2.5\%), tem-se quase $95 \%$ da receita estimada para aquele ano. Evidência de certa fragilidade do sistema tributário. Afinal, a concentração da receita em apenas quatro rubricas poderia resultar em fracasso na arrecadação, caso fatores econômicos ou de qualquer outra natureza levassem à redução nos fatos geradores de um ou mais desses tributos.

O tabela 2 relaciona a arrecadação prevista para o exercício de 1911, conforme autorização definida pela Lei 533, de 24 de setembro de 1910 (Collecção, 1911, pp. 23-37). Nas receitas orçamentárias para 1910, portanto em ponto intermediário da República Velha, podem ser observadas consideráveis alterações em relação ao início do período. As receitas subdividiam-se em renda ordinária e renda extraordinária e a participação relativa das diversas receitas estava algo diluída, não vigorando excessiva concentração em uma ou poucas rubricas. O imposto de exportação, embora permanecesse como o principal componente da receita, perfazia participação bem inferior a que apresentava no final do século XIX: $38.2 \%$ da renda total. A segunda maior participação relativa é a da cobrança da $s 0^{-}$ bretaxa do café (cuja inclusão entre as rubricas da renda extraordinária denota seu caráter eventual), com 19.3\% da receita total. Somada a participação destas duas rubricas à do imposto sobre exportação de ouro e diamantes (1.3\%), verifica-se que o comércio exterior, apesar de em menor patamar, ainda era responsável por $58.9 \%$ da arrecadação do Estado.

O tabela 3 apresenta o detalhamento das receitas estimadas para o ano fiscal de 1929, conforme autorização contida na Lei 1.060, de 2 de outubro de 1928 (Collecção, 1929, pp. 101-108). Constatam-se evidentes aperfeiçoamentos na elaboração do orçamento, apresentado de forma mais estruturada e racionalizada. Reitera-se também a menor dependência da receita para com alguns poucos tributos, vigorando melhor distribuição da arrecadação orçamentária. As receitas se subdividiam em renda ordinária (81.2\% da arrecadação) e renda extraordinária (18.8\% da arrecadação).

A renda ordinária era composta pelos impostos $(62 \%)$, rendas patrimoniais $(1.3 \%)$ e rendas industriais $(18 \%)$. O principal imposto era o de direitos de exportação, que, com a sobretaxa do café e o adicional sobre exportação de manganês, respondia por $31.6 \%$ de toda a arrecadação. Ou seja, o declínio da participação da arrecadação gerada pelo comércio exterior torna-se ainda mais evidente a essa altura da Primeira República. Destaques também para o imposto territorial $(5.5 \%)$ e o de indústrias e profissões $(5 \%)$. As rendas patrimoniais eram de pouca relevância. Das rendas 


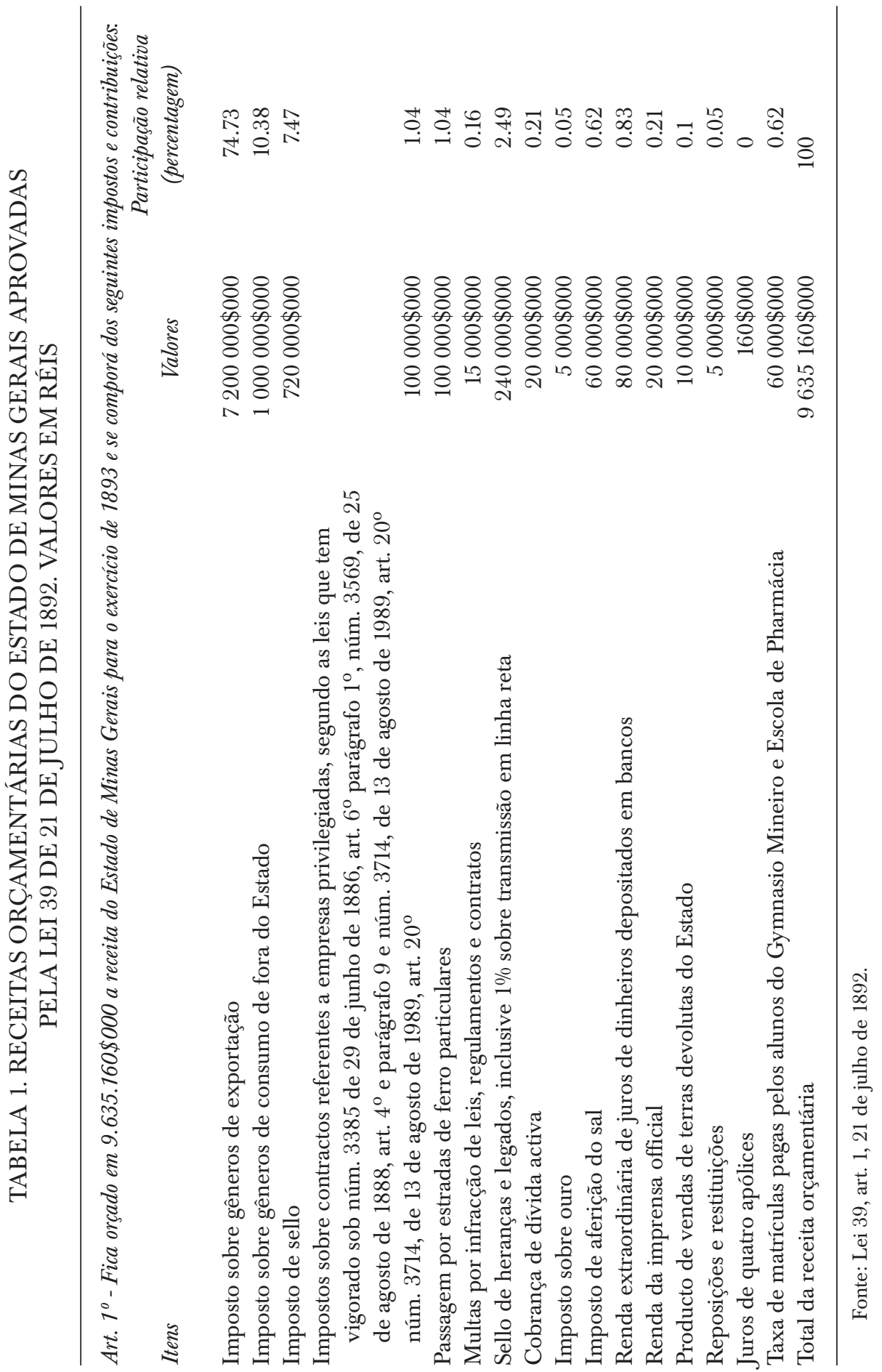




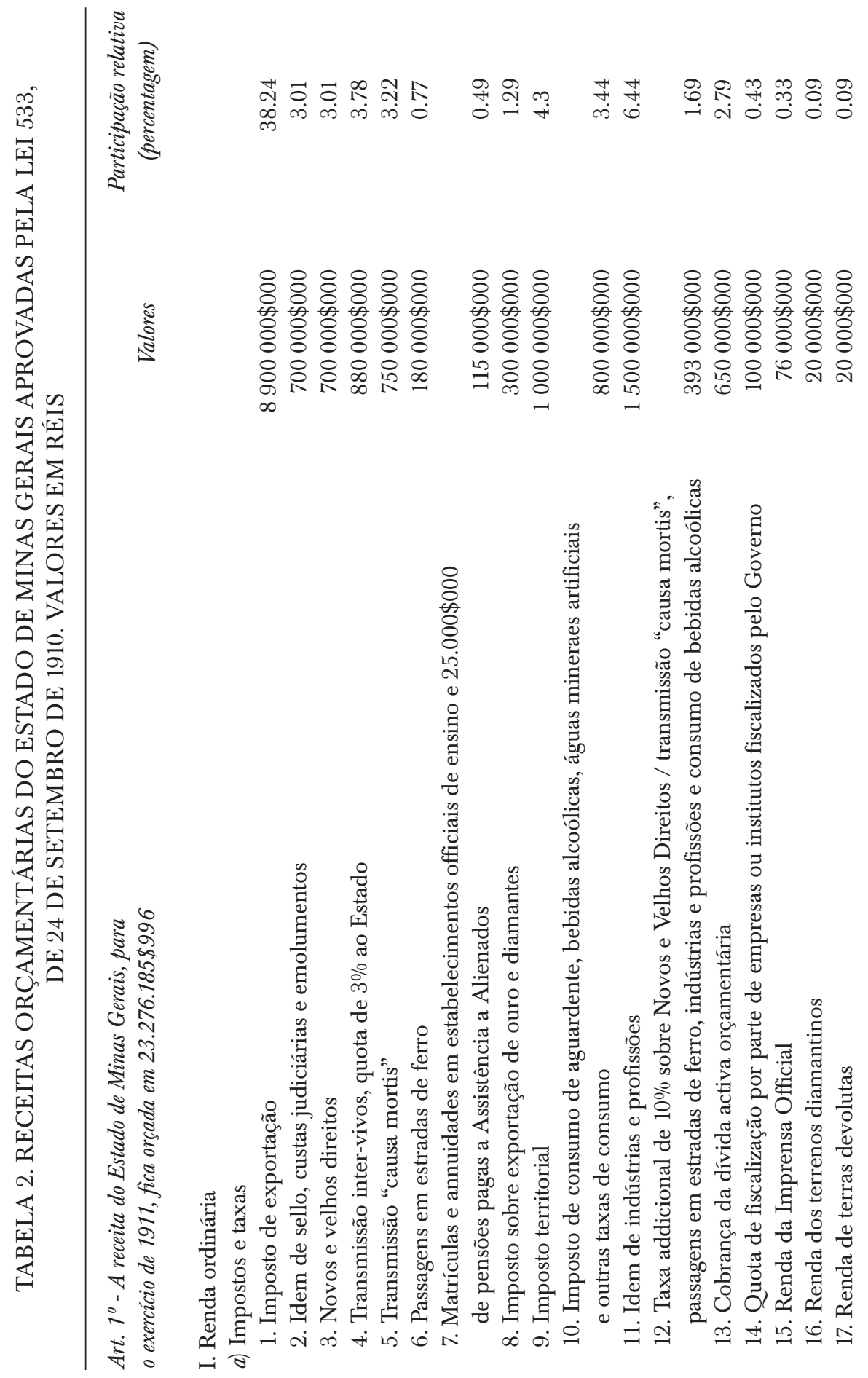




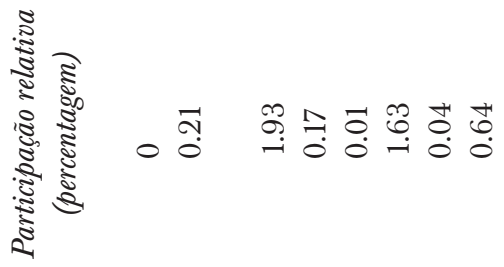

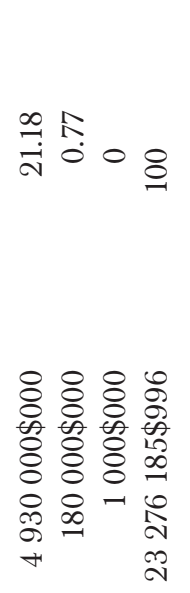

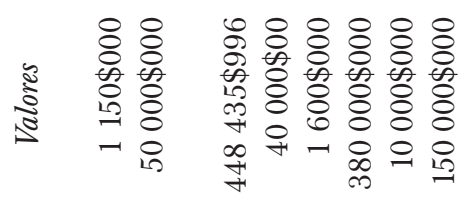

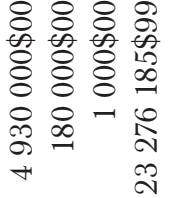

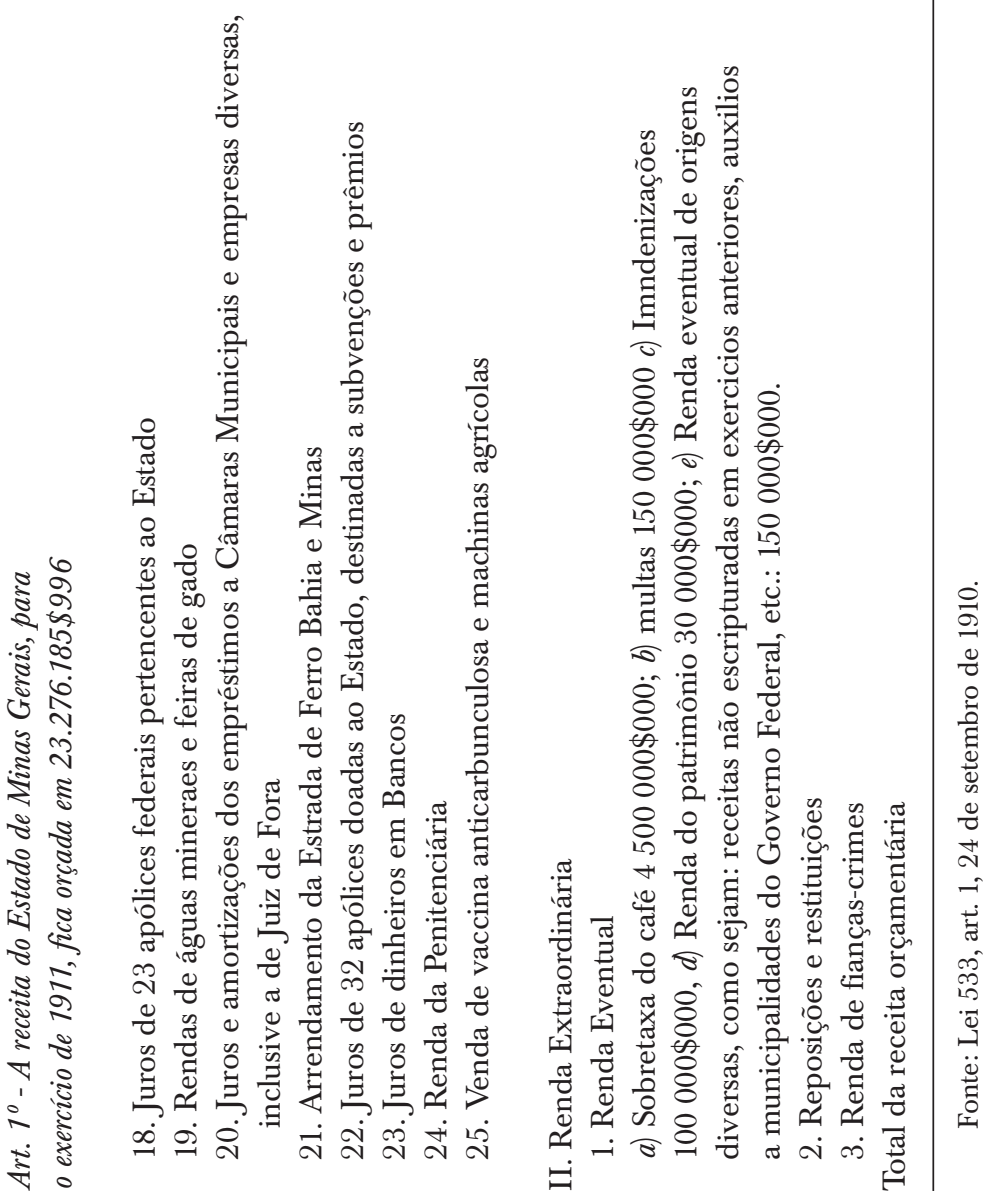


industriais, ressalta a receita da Rede Sul Mineira (ferrovias), com 10.3\% da receita total. Entre as rendas extraordinárias, a de maior destaque era a do imposto de defesa do café, que, sem explicação, não era incluído entre os demais impostos. Este item representou $8.6 \%$ da receita estimada para o exercício de 1929.

A Lei 1.060 previa também a realização de operações de crédito por antecipação de receitas. Operações que parecem justificáveis, se considerado que a arrecadação estadual era essencialmente ancorada na tributação de atividades primárias (notadamente a agropecuária) e, portanto, sujeitas à incidência de fatores sazonais. Enquanto no transcurso do ano fiscal as receitas apresentavam picos e vales, as despesas eram quase que lineares, a impor a mobilização de mecanismos para financiar os períodos de baixa arrecadação.

Comparadas as estruturas das receitas de Minas Gerais (1892, 1910 e 1928) constata-se, adicionalmente a diversificação das fontes de arrecadação e do declínio relativo das rendas originárias do comércio exterior, a vigência de mudança orientada pela modernização da estrutura tributária, ou na direção da progressiva incidência sobre a renda e a riqueza. Wilma Costa sublinhou o engessamento que as oligarquias regionais operaram na Constituição de 1891 e regulamentações posteriores, com o objetivo de repor "os bloqueios que impediam que a extração fiscal atingisse de forma direta a riqueza e a propriedade das elites agrário-exportadoras" (1998, pp. 166 e 169). Assim, as receitas alfandegárias persistiram no centro da arrecadação, acrescidas gradualmente de recursos originários de atividades de mercado interno, sobretudo aquelas associadas ao desenvolvimento urbano e a industrialização. Nestes termos, o caso de Minas Gerais representaria estágio relativamente mais avançado do progressivo esvaziamento da excessiva concentração da arrecadação sobre o comércio externo.

Entre as fontes de receita que cresceram em importância no transcurso da Primeira República, e que progressivamente reduziram a participação relativa da arrecadação sobre o comércio externo, destaca-se o imposto territorial. Segundo a Lei 282, de 18 de setembro de 1899, incluiu-se pela primeira vez o imposto territorial no Orçamento da Receita de Minas Gerais, com arrecadação projetada de 2500 contos de réis, que correspondiam a segunda maior fonte de recursos fiscais. A criação do novo imposto implicava a redução da alíquota do imposto de exportação sobre o café, que passaria de 9 para $11 \%{ }^{12}$ (Collecção, 1900, pp. 44-51). Entretanto, a

${ }^{12}$ Certamente não era coincidência a criação do imposto territorial na conjuntura do final do século XIX e início do século XX, dada a crise do café e suas repercussões sobre a estrutura fiscal dos estados cafeeiros, por demais dependentes de receitas originárias do comércio exterior, como era o caso de Minas Gerais. Para além da conjuntura de crise do setor exportador, as evidências revelam propósito irreversível quanto à alteração da base tributária, como se pode depreender 


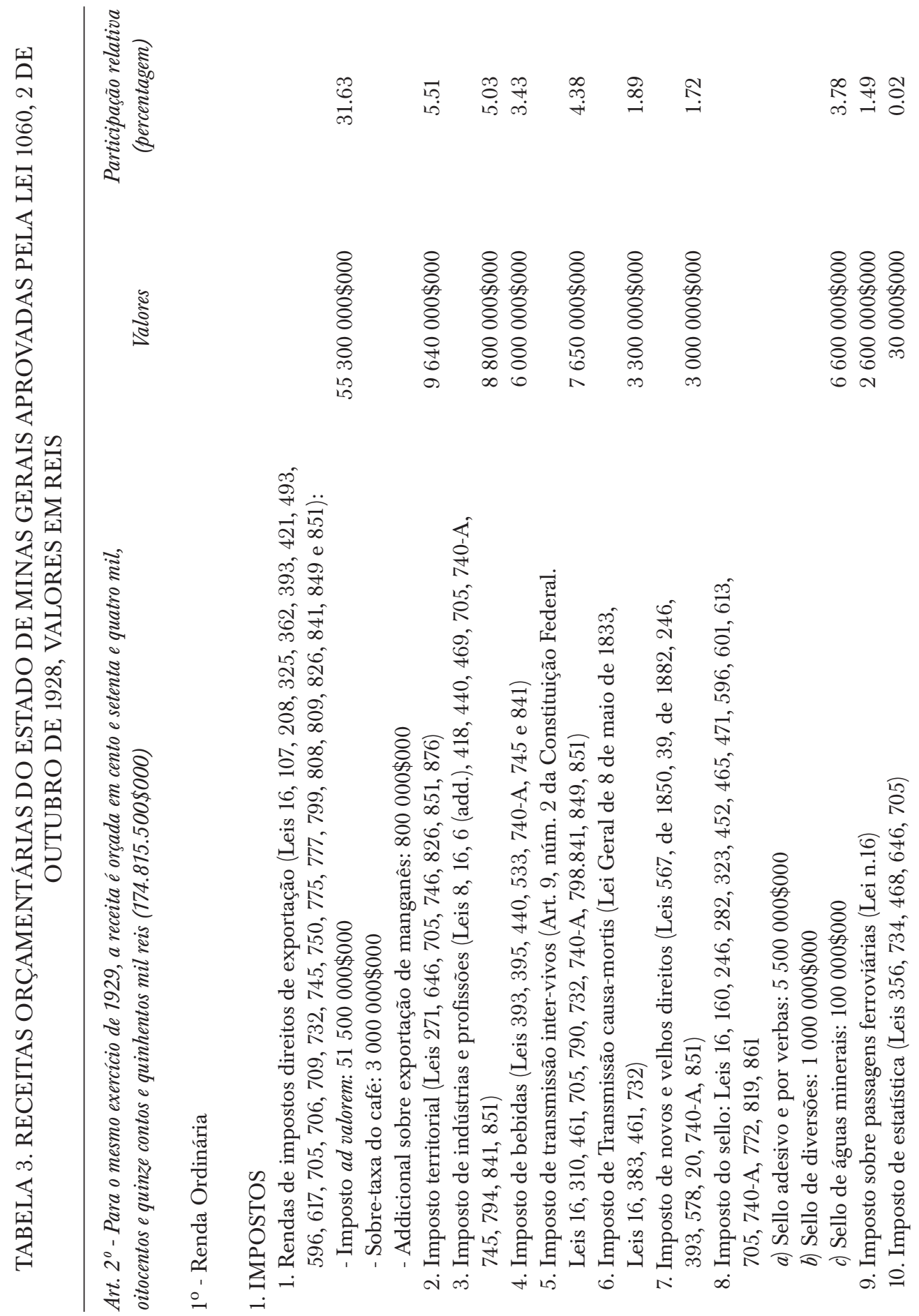




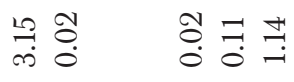
$\stackrel{9}{9}$
準

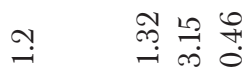

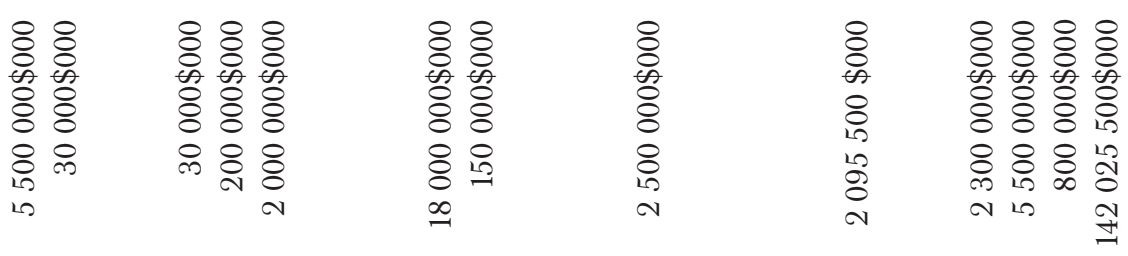
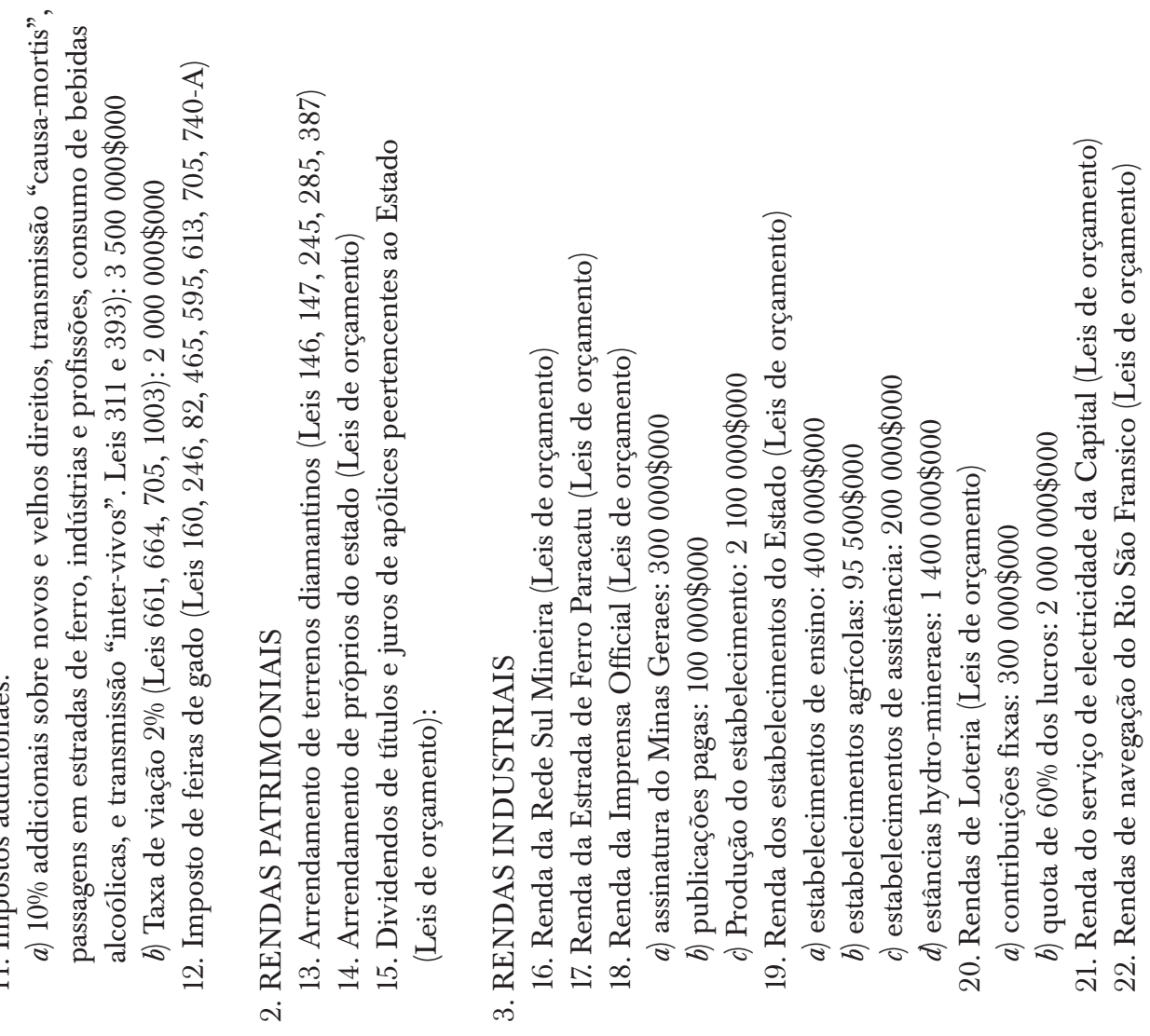


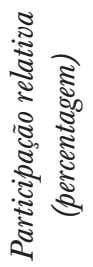

$$
\text { 팓 }
$$
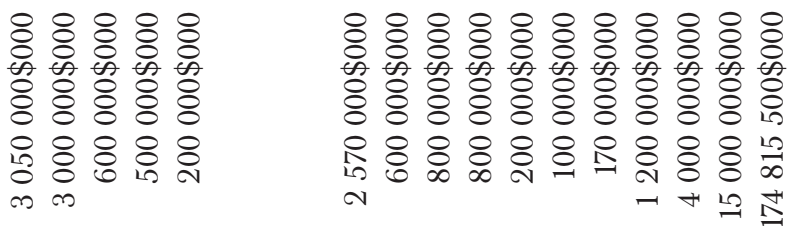

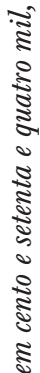
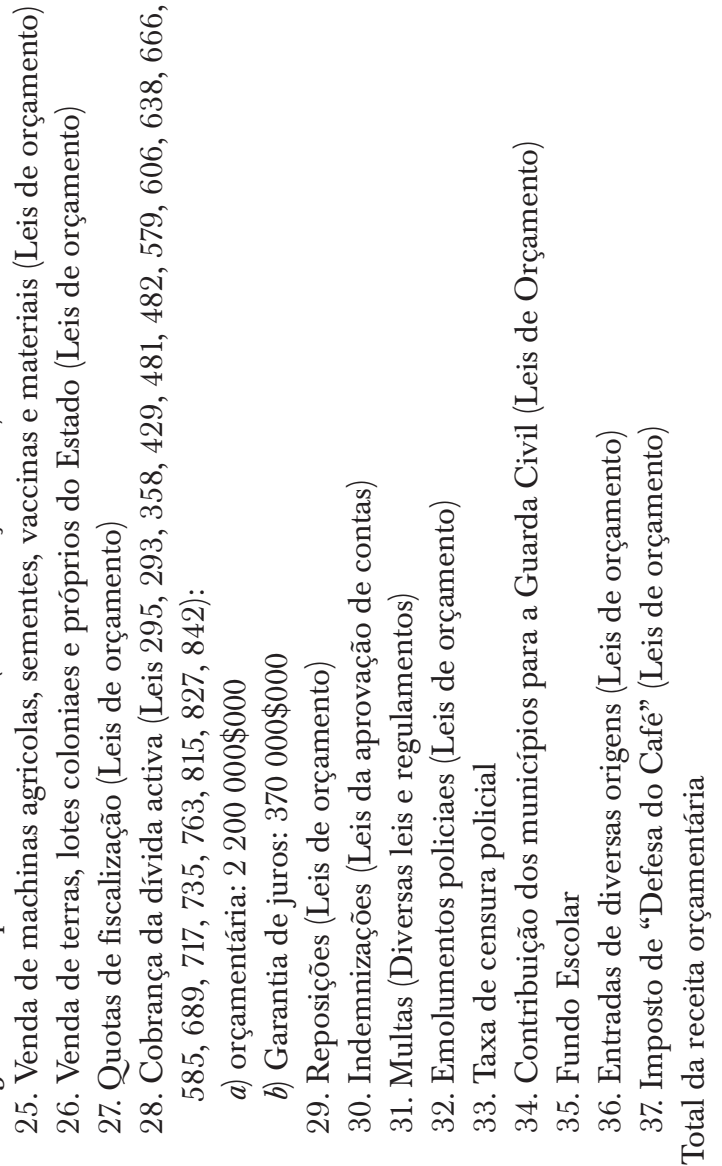
implantação do novo imposto demoraria algum tempo, tendo em vista que o Congresso Mineiro posteriormente "alterou a taxa e modificou a incidencia do imposto", com substantiva redução na projeção da arrecadação. Arrecadação que se efetivou pela primeira vez no exercício fiscal de 1901, quando "o producto do imposto territorial attingiu a 964:241\$416", superando a projeção orçamentária de 950 contos de réis (Mensagem, 1902, pp. 47-48).

Ao pioneirismo do estado de Minas Gerais na criação e na efetiva implantação do imposto territorial no Brasil, ${ }^{13}$ seguiu-se à consolidação do novo tributo, pelo que se pode depreender do desempenho de sua arrecadação nas primeiras décadas do século XX..${ }^{14}$ Com certa estabilidade dos valores arrecadados entre 1901 e 1914, quando flutuaram entre, aproximadamente, 800 e 1000 contos de réis, a exação do imposto territorial conheceu forte movimento de expansão entre 1915 e 1929, quando passou de, aproximadamente, 1400 para 10800 contos de réis. Em termos relativos, o imposto territorial flutuou entre, aproximadamente, 4 a $9 \%$ da receita tributária do estado, média de $6.5 \%$, e tendência de expressivo crescimento no último quinquênio da República Velha -de 6.8\% em 1926 para 9.3\% em 1929 (Minas Gerais, 1954). ${ }^{15}$ Em estudo encomendado pelo governo

da tese número 57, do Congresso Agrícola, Industrial e Comercial de Minas Gerais, realizado em 1903: "Uma vez aceito o imposto territorial como base do sistema tributário mineiro, convém a adoção de um regime mais ou menos modelado pela Lei de Torrens, para o fim de mobilizar a riqueza territorial imóvel?”. A resposta consta da primeira conclusão apresentada pela Comissão Fundamental do Congresso: "1. Convém que o imposto de exportação sobre o café seja lenta e progressivamente substituído pelo imposto territorial” (Minas Gerais, 1981, p. 127).

${ }^{13}$ Pioneirismo que diverge de atribuição comum na historiografia quanto à precedência ou mesmo originalidade do Rio Grande do Sul em estabelecer o imposto territorial na República Velha (Costa, 1998, p. 168).

${ }^{14}$ A implantação do imposto territorial em Minas Gerais conheceu forte oposição por parte dos grandes proprietários, que se organizaram no legislativo e em dois congressos de produtores agrícolas, com o objetivo de reduzir ao máximo o impacto tributário da nova imposição (Wirth, 1982, pp. 176-178).

${ }^{15}$ Luiz Roberto Targa (2008) atribuiu exclusividade ao Rio Grande do Sul na efetiva implantação do imposto territorial, combinada com reestruturação fiscal que reduziria a dependência do Estado com relação ao imposto sobre exportações, bem como afirmou que apenas nessa unidade da Federação "este imposto produziu receitas importantes para os cofres públicos" (pp. 5 e 13). O cotejo dos valores da arrecadação do imposto territorial (IT) e de seu peso relativo entre Minas Gerais (MG) e o Rio Grande do Sul (RS) não confirmam as conclusões do autor. Entre 1904 e 1910 o RS arrecadou 11504 contos de réis com o IT, média anual de 1643 , e a representar $15.5 \%$ da arrecadação tributária no período, enquanto MG arrecadou 6138 contos de réis com o IT, média anual de 877, e a representar 5.8\% da arrecadação tributária no período. Entre 1911 e 1920 o RS arrecadou 29962 contos de réis com o IT, média anual de 2996 , e a representar $15.6 \%$ da arrecadação tributária no período, enquanto MG arrecadou 14602 contos de réis com o IT, média anual de 1460 , e a representar 4.6\% da arrecadação tributária no período. Entre 1921 e 1929 o RS arrecadou 55946 contos de réis com o IT, média anual de 6216 , e a representar $11.1 \%$ da arrecadação tributária no período, enquanto MG arrecadou 58353 contos de réis com o IT, média anual de 6484 , e a representar 7.3\% da arrecadação tributária no período. Portanto, na última década da República Velha a arrecadação em termos absolutos do IT em MG ultrapassou a do RS, 
estadual e publicado em 1931, João Pandiá Calógeras (1931) apresentou "sugestões" para a reforma tributária de Minas, estruturada em forte redução dos impostos de exportação compensada por pronunciado aumento do imposto territorial. A proposta do eminente engenheiro e político parece ter se efetivado nos anos seguintes, com o substantivo crescimento da arrecadação do imposto territorial e a correspondente ampliação de sua participação relativa na receita tributária do estado. Na década de 1930, o imposto territorial respondeu, em média anual, por $13.1 \%$ da receita tributária, contra 7.9\% na década de 1920. A arrecadação média anual do imposto territorial na década de 1930 ultrapassou 18000 contos de réis, contra menos de 7000 contos de réis na década de 1920 .

Por fim, propõe-se a hipótese de correlação entre a diversificação da estrutura da receita e a diversificação da economia de Minas Gerais no transcurso da República Velha. Ainda que o setor de mercado externo do estado tenha apresentado crescimento constante no período, sobretudo por meio da expansão cafeeira, verificou-se diversificação no sentido do crescimento mais do que proporcional do setor de mercado interno. ${ }^{16}$

\section{Estrutura do orçamento da despesa}

As despesas previstas em orçamento foram classificadas em sete grupos, de acordo com a natureza e/ou destinação. O serviço da dívida compreendia os gastos orçados para pagamento de amortizações, juros e encargos da dívida fundada interna e externa. A administração superior incluía as despesas da administração superior do Estado, a saber: subsídios e representação do presidente e vice-presidente do Estado, despesas de gabinete, custeio dos palácios, pessoal de apoio da Secretaria do Interior, subsídios e ajuda de custo de senadores e deputados, custeio da Câmara e do Senado, Magistratura e Justiça e Promotoria Pública do Estado, inclusive custeio. As obras públicas correspondiam a valores consignados em orçamento especificamente com essa finalidade, a abranger não só a rubrica do mesmo nome, mas outras consideradas da mesma natureza (como as estradas de rodagem). As subvenções e garantias de juros a estradas de ferro eram es-

com importante recuo do peso relativo do IT na receita tributária do RS e considerável avanço em MG. São indicadores do quanto à consolidação de uma matriz tributária moderna, que guardava certo caráter progressivo, encontraria resistência por parte dos proprietários fundiários no estado do Rio Grande do Sul, pioneiro na redução substantiva da dependência do imposto sobre exportações, bem como do quanto seria demorada a consolidação de estrutura fiscal diversificada no estado de Minas Gerais, precursor na implantação do imposto territorial (Targa, 2008, p. 18; Minas Gerais, 1954).

${ }^{16}$ A tendência de diversificação da economia de Minas Gerais na República Velha foi ressaltada por Martins Filho (2009, pp. 35, 40, 60, 92). 
pecíficas para os gastos com a expansão ferroviária na forma de subsídios públicos. A saúde e assistência abarcavam as verbas para sustento, vestuário e curativos dos presos pobres, socorros públicos (inclusive Diretoria de Higiene), assistência a alienados e subvenções diversas destinadas a abrigos, asilos, hospitais, santas casas, entre outras. O Estado não alocava em orçamento verba destinada a ações de saúde, já que nem sequer existia órgão específico para execução de políticas públicas. A proposta orçamentária para 1923 faz menção a Diretorias e Delegacias Regionais de Higiene. As despesas com educação compreendiam os gastos diretos relacionados com o ensino público, incluindo pessoal, custeio e investimentos, fornecimento de material escolar, livros, mobiliário e subvenções a instituições privadas de ensino. A segurança pública agrupava todas as dotações orçamentárias relacionadas à segurança, tais como gastos com a força pública -incluindo pessoal militar, custeio, manutenção e investimentos-, delegacias de polícia, cadeias públicas, penitenciárias, guarda civil da capital.

Os gráficos 3 e 3.A apresentam a distribuição, em milhares de contos de réis, dos valores das despesas orçadas. Observa-se tendência geral de crescimento progressivo para todos os grupos de despesa até o início da década de 1920, quando se observa aceleração no incremento. Essa evolução pode ser explicada não apenas pelo crescimento das receitas, conforme observado anteriormente, mas também pela melhoria da técnica na elaboração das propostas orçamentárias, que passam a incluir e classificar com maior abrangência tanto as receitas quanto as despesas.

O gráfico 3.B faculta a observação da evolução da participação relativa por agrupamento de despesa orçamentária. O serviço da dívida será objeto de análise no próximo tópico. A administração superior apresentou tendência de progressiva queda da participação relativa, de destacada posição no início do período (mais de $20 \%$ no começo da década de 1890) para posição pouco relevante no final da Primeira República (em torno de $5 \%$ da despesa), conquanto não apresentou tendência de queda nominal de valores, que, ao contrário, conhecem importante inflexão de alta na década de 1920 (ver gráficos 3 e 3.A.). Segundo dados apresentados por Mendes (2007, pp. 37-39), a participação relativa das despesas administrativas não só apresentou muito maior importância no império comparado com a República Velha, como ainda mostrou leve tendência ascendente no transcurso do período imperial.

Nas três primeiras décadas da República Velha, os investimentos em obras públicas eram pequenos se comparados aos das demais despesas. A política do Estado reservava ao setor privado a maior parte dos investimentos diretos, principalmente em infraestrutura de transportes, ainda que comumente sob fortes subsídios dos governos dos estados e da União. 


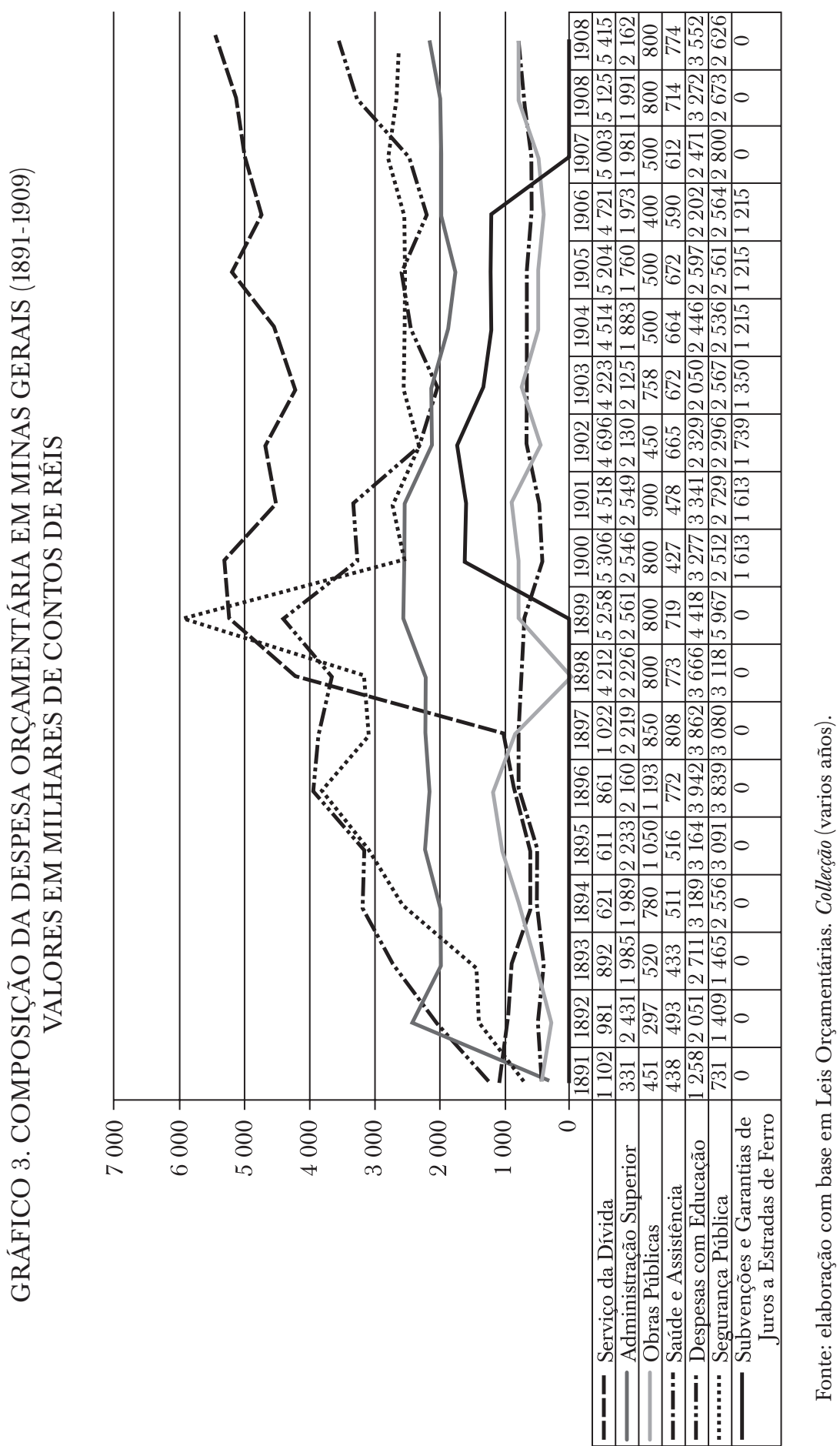




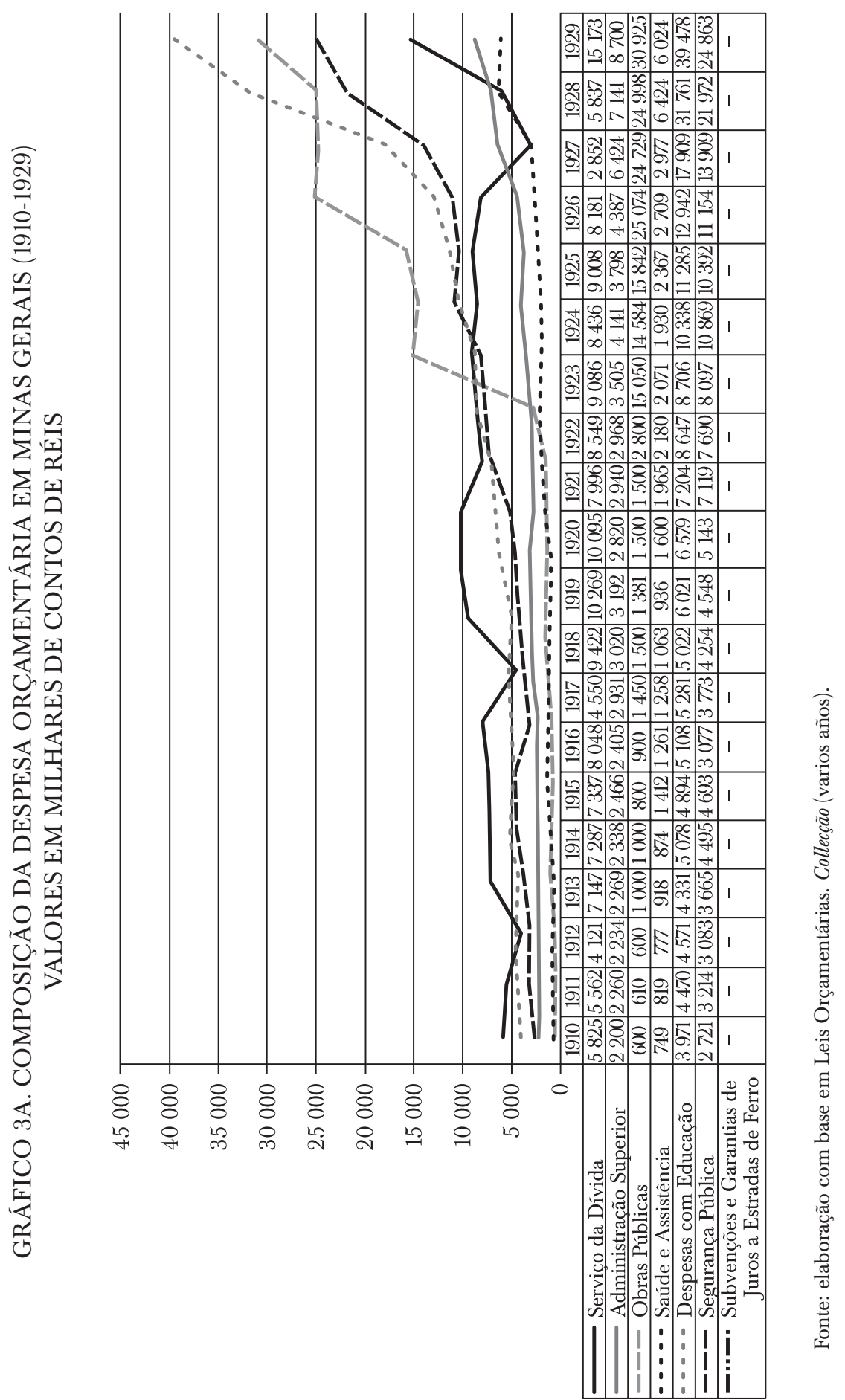


Em 1916 foi registrada a primeira alocação orçamentária para construção de rodovias. Somente a partir de 1923, com a Rede Sul Mineira de Viação e a Estrada de Ferro Paracatu, se constata uma mais efetiva participação direta do Estado em obras de infraestrutura, inclusive a alçar esta rubrica na década de 1920 à posição de mais importante no quadro das despesas. Para o conjunto do período imperial, segundo dados de Barbosa, Godoy e Mendes (2011, pp. 247-248), a participação dos gastos em obras públicas se mostrou bem mais relevante que para o conjunto do período da Primeira República, ainda que mostrasse tendência ao declínio no primeiro caso e tendência ascensional no segundo.

As subvenções e garantias de juros a estradas de ferro vigoraram nos orçamentos apenas durante um curto período de tempo (1900-1906), sem que se possa estabelecer a forma como esses subsídios foram escriturados nos períodos anteriores e posteriores da República Velha, posto que é contínua a vigência dessas formas de subvenção desde as últimas décadas do século XIX e persistiu, ainda que com redução progressiva, durante as primeiras décadas do século Xx (Acioli, 2007, pp. 7-35). No império, essa modalidade de despesa não foi registrada de forma específica na escrituração financeira dos orçamentos e na execução orçamentária do governo provincial (Barbosa, Godoy e Mendes, 2011, pp. 249-250).

Saúde e assistência não constituíam prioridade governamental. Os gastos apresentaram comportamento praticamente linear durante toda a Primeira República, nunca superando 5\% da despesa total, excetuados os primeiros anos do período. Praticamente não se investia em unidades próprias de saúde, em programas de prevenção e saneamento, destinando-se os recursos a auxílios e subsídios a instituições privadas. Somente quase ao final do período foram criadas unidades próprias de saúde, bem como a Diretoria de Saúde Pública, vinculada à Secretaria de Segurança e Assistência. Em 1928, além desta diretoria, existiam dotações orçamentárias para o Hospital Central de Barbacena, para o Manicômio Judiciário e para o Instituto Raul Soares -entidades especializadas em doenças mentais. No período imperial, as despesas com saúde também nunca ganharam projeção relativa (Mendes, 2007, p. 37).

As despesas com educação sempre mereceram atenção especial dos governantes mineiros da República Velha. Observa-se que razoável parcela do orçamento era comprometida com a educação, cujos gastos se mantiveram tendencialmente constantes durante o período, sempre entre os três grupos de despesas com maior participação relativa. Além de sua política própria de investimentos no setor, o governo estadual também contribuía com subsídios a instituições privadas e com convênios com municípios. Ao final do período, o governo participava em todos os níveis da educação: ensino primário, ensino secundário, ensino superior, ensi- 
no normal, ensino artístico e ensino profissional. Dados apresentados por Mendes (2007, pp. 37-39) indicam que não só a participação dos gastos em educação foi frequentemente maior no império que na república, como tendia a crescer.

O dispêndio orçamentário com o setor de segurança pública era considerável, sendo superado apenas pelos gastos com educação. A participação relativa no total das despesas também era bastante uniforme no tempo, com picos em anos em que se incorporavam novos batalhões ou se construíam novas unidades militares. Entretanto, segundo dados apresentados por Mendes (2011, pp. 37-39), a participação dessas despesas no império tendeu a superar a dos gastos da mesma natureza realizados na República Velha.

No excessivo peso do serviço da dívida na República Velha, o principal grupo de despesas na maior parte do período, está a explicação para a participação relativa mais expressiva no império dos demais grandes grupos de despesas (administração, obras públicas, educação e segurança).

\section{A dívida pública e o serviço da dívida}

Objetiva-se agora dimensionar o peso do serviço da dívida pública sobre as finanças estaduais. Na ausência de relatórios precisos sobre a execução orçamentária, foram considerados os dados orçamentários. Os estoques de dívida fundada foram extraídos, quando disponíveis, dos relatórios enviados ao poder legislativo, sendo que nos casos de indisponibilidade ou inconsistência dessa informação quanto à sua exação, optou-se pela notação n. d. (não disponível). Preferiu-se também considerar os saldos devedores na moeda original, visto que estes quase nunca eram convertidos em réis, e também por não disponíveis nos Relatórios as taxas cambiais para conversão. $\mathrm{O}$ tabela 4 apresenta os estoques de dívida fundada e as dotações orçamentárias necessárias ao atendimento do serviço da dívida a cada exercício.

Observa-se, de modo geral, um elevado comprometimento das despesas públicas do Estado de Minas Gerais com o serviço da dívida (tabela 4 e gráfico 4). Na República Velha, o serviço da dívida anual foi, em média, de $5617125 \$ 000$, e correspondeu, também em média, a 19\% da despesa total 


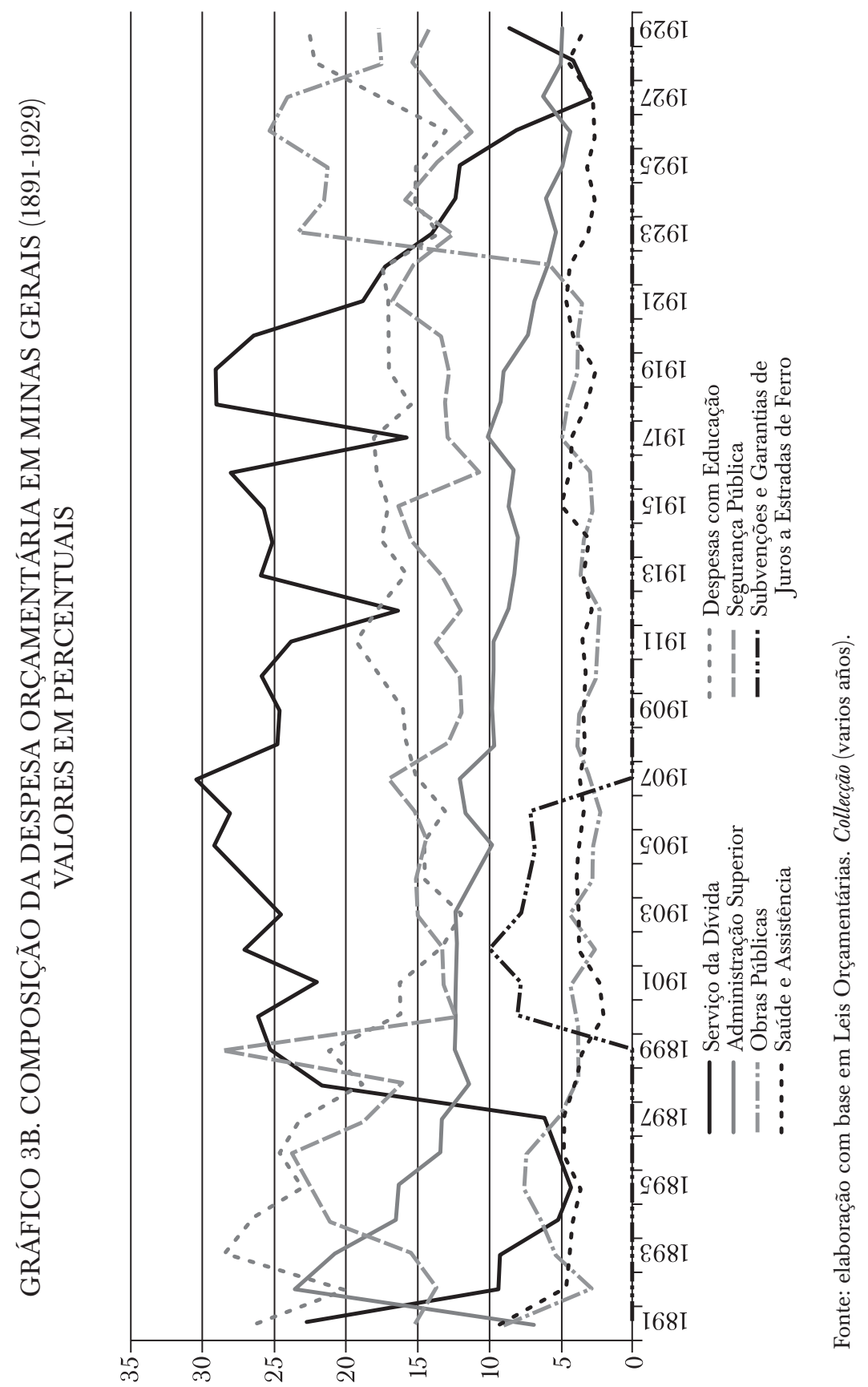




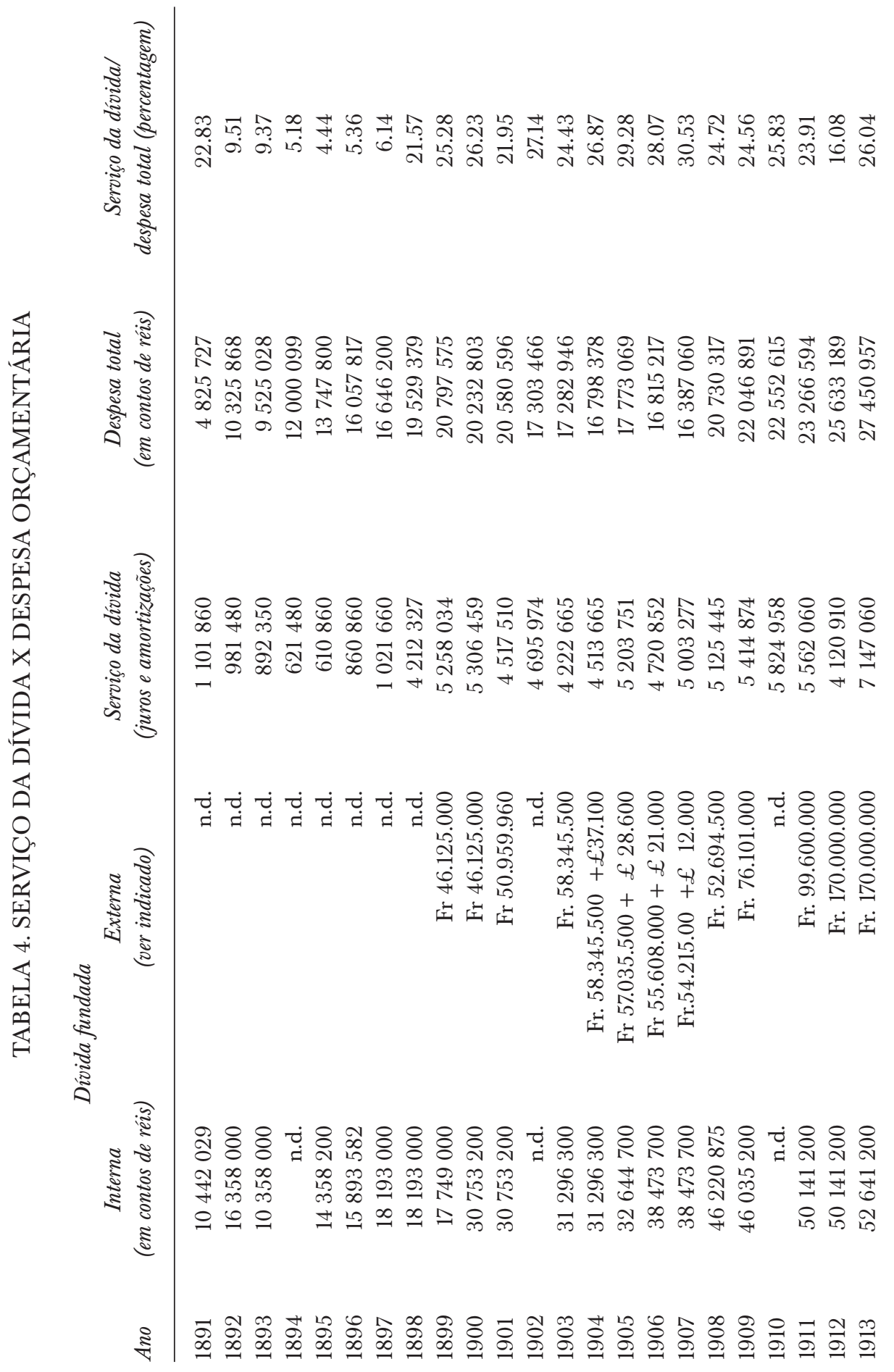




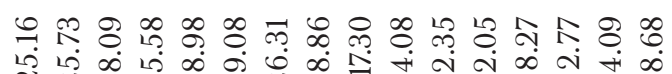
ง

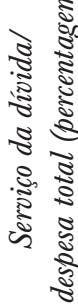

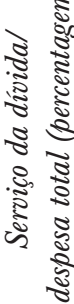

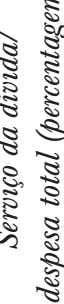

离恋 范 芯 $\stackrel{\infty}{\sim} \stackrel{\infty}{\sim} \stackrel{\sim}{\sim}$ 网

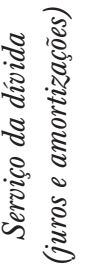

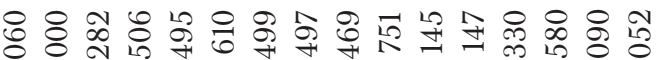

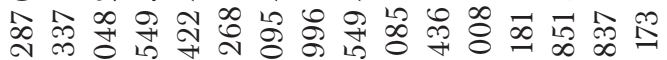

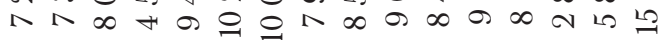

ลี

\& \& \& 웡

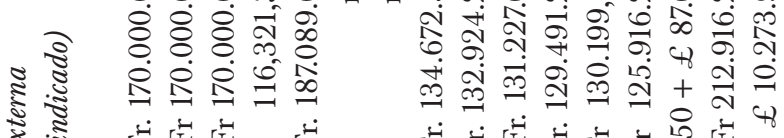

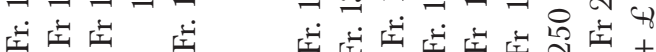

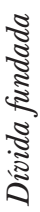

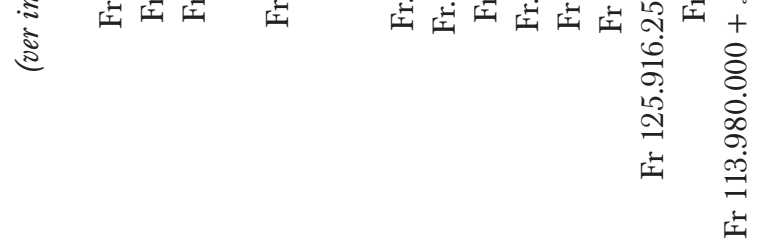

ॠ

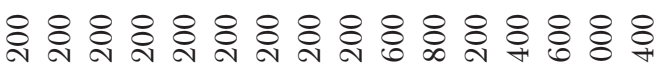

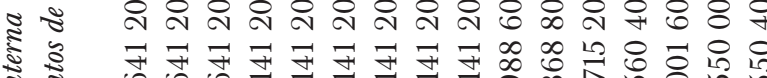

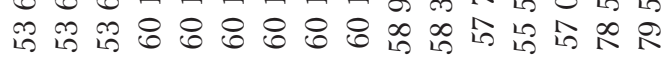
胥

:

द्व

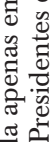

:ुำ

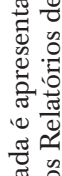

莺

要通

这

啳

总元

ลิ

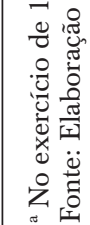

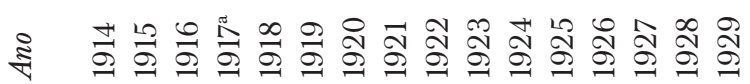


anual. ${ }^{17}$ Em 1907 essa participação atingiu o pico de $30.5 \%{ }^{18}$ As evidências são de largo predomínio da origem francesa dos empréstimos. ${ }^{19}$

Avalia-se que as estimativas para o serviço da dívida levavam em conta não apenas a dívida fundada, mas também as operações de crédito por antecipação de receita. Como ressaltado anteriormente, as rendas públicas eram altamente dependentes da tributação de produtos primários, geralmente agrícolas e, portanto, bastante sazonais. Por outro lado, as despesas eram lineares, com compromissos mensais, daí a necessidade de se captar recursos de curto prazo.

Conquanto o crescimento em termos absolutos da dívida apresente inequívoca tendência ascendente no período, com oscilação na década de 1920 e crescimento vertiginoso em 1929, a participação relativa do serviço da dívida na despesa total (ver gráfico 3.B), após ter se mantido em níveis elevados nas décadas intermediárias, ou entre 1900 e 1920, mostrou tendência declinante na última década da Primeira República, retomando níveis similares ao da primeira década do período. Essa evolução do peso relativo do serviço da dívida estadual parece se explicar pela combinação dos seguintes fatores: $a$ ) o crescimento absoluto do serviço da dívida não encontrou correspondente crescimento da receita total entre a primeira e a segunda década da República Velha, com a consequente forte expansão relativa dessa rubrica na despesa total e sua manutenção em níveis altos na segunda e terceira décadas; $b$ ) ao contrário, na última década da República Velha, à forte ascensão da dívida em termos absolutos correspondeu crescimento muito mais do que proporcional da receita total estadual, com a correspondente declinante participação relativa dessa rubrica na despesa

\footnotetext{
${ }^{17}$ Wirth avaliou nos mesmos termos a evolução do serviço da dívida, que "era, em média, $20 \%$ do orçamento real entre 1897 e 1923 " (1982, p. 288).

${ }^{18}$ Costa e Deos (2002, p. 24) ressaltaram o caráter estrutural do endividamento brasileiro, por meio de empréstimos no exterior desde o início do período imperial, "em condições extremamente onerosas para o país, raramente articulados a um projeto de desenvolvimento econômico", e a sustentar círculo vicioso de expansão da dívida, ante os crescentes compromissos de pagamentos de juros e amortizações, que engendravam a necessidade de novos empréstimos.

${ }^{19}$ Minas Gerais foi o segundo governo estadual a captar empréstimo externo na República Velha, cabendo ao Espírito Santo a primeira iniciativa. O governo mineiro "contratou, em 12 de outubro de 1896, a soma de 65 milhões de francos (68 800 contos de réis) junto ao Banque de Paris et dês Pays Bas. O valor líquido do empréstimo (cerca de 53600 contos de réis) correspondeu a 2.8 vezes o valor da receita estadual arrecada durante o ano". Entre 1894, ano do primeiro empréstimo externo de governo estadual, e 1913, às vésperas da primeira guerra mundial, que promoveu a retração dos fluxos internacionais de capitais, foram contratados 31 empréstimos externos pelos estados brasileiros, sendo que Minas Gerais respondeu por cinco operações de crédito externo. Os empréstimos mineiros no período totalizaram 188.286 contos de réis, ou $25.7 \%$ do volume de recursos captados no exterior pelos governos estatuais. No pós-Guerra, entre 1919 e 1931, foram contratados 37 empréstimos externos pelos estados brasileiros, sendo que Minas Gerais respondeu por três operações de crédito externo. Os empréstimos mineiros no pós-guerra totalizaram 208652 contos de réis, ou $6.9 \%$ do volume de recursos captados no exterior pelos governos estaduais (Maia e Saraiva, 2012, pp. 112, 116-118 e 122-127).
} 
total. Adicionalmente é sugestiva a influência da curva da participação relativa dos empréstimos estaduais e municipais no período, que passam de cerca de 4\% do endividamento externo total do Brasil em 1895 para cerca de 30\% em 1930 (Abreu, 1999, p. 2), ${ }^{20}$ sendo que entre 1927 e 1931 o serviço da dívida (flutuante e consolidada) representava, em média, 19.7\% da despesa das municipalidades mineiras (Minas Gerais, 1937, p. 277).

\section{Entre o equilíbrio orçamentário e o desenvolvimento}

Nos seguintes termos Iglésias sintetizou o comportamento dos homens públicos mineiros da Primeira República em relação às finanças:

A situação financeira do Estado atesta a relativa estagnação e a falta de dinamismo de seus administradores. Minas tende mais que outras unidades ao equilíbrio orçamentário -miragem da época; é tímida nos gastos, parca em investimentos; tem horror a empréstimos, internos ou externos, como é da natureza dos cautelosos, evitando como temerárias as iniciativas de endividamento (Iglésias, 1982, p. 132).

De fato, nos relatórios dos presidentes do Estado, em especial na primeira metade da República Velha, são frequentes as manifestações explícitas da preocupação com o equilíbrio orçamentário. Longos trechos são dedicados somente à discussão da situação financeira de Minas Gerais e, frequentemente, constata-se a ausência de políticas voltadas à promoção do desenvolvimento. Entretanto, desde o início do século XX, despontam discursos em que se combina a tradicional preocupação com o equilíbrio orçamentário e o problema do desenvolvimento econômico regional. Como se constata no Relatório do presidente Francisco Sales em 1904: ${ }^{21}$

Si merecerem vosso acolhimento os alvitres lembrados e vos parecer acertado completal-os com outras medidas inspiradas pelo vosso patriotismo, certo conseguir-se-á o restabelecimento do equilibrio financeiro do Estado, ainda que com sacrificio dos serviços publicos [...] Não se comprehende o abandono pelos poderes publicos das actividades productoras, da agricultura e da industria, quando é da

${ }^{20}$ Segundos os dados do Repertório Estatístico do Brasil (IBGE, 1941, p. 132), em 1930 a dívida externa consolidada dos estados e municípios representava $44.3 \%$ da dívida externa total do Brasil, respondendo os estados por $34.2 \%$ e os municípios por 10.1 por cento.

${ }^{21}$ Realizado em 1903, no governo de Francisco Sales e presidido por João Pinheiro, o Congresso Agrícola, Industrial e Comercial é considerado marco da emergência do desenvolvimento regional politicamente orientado em Minas Gerais. Sobre o Congresso ver Dulci (1999, pp. 43-48). 


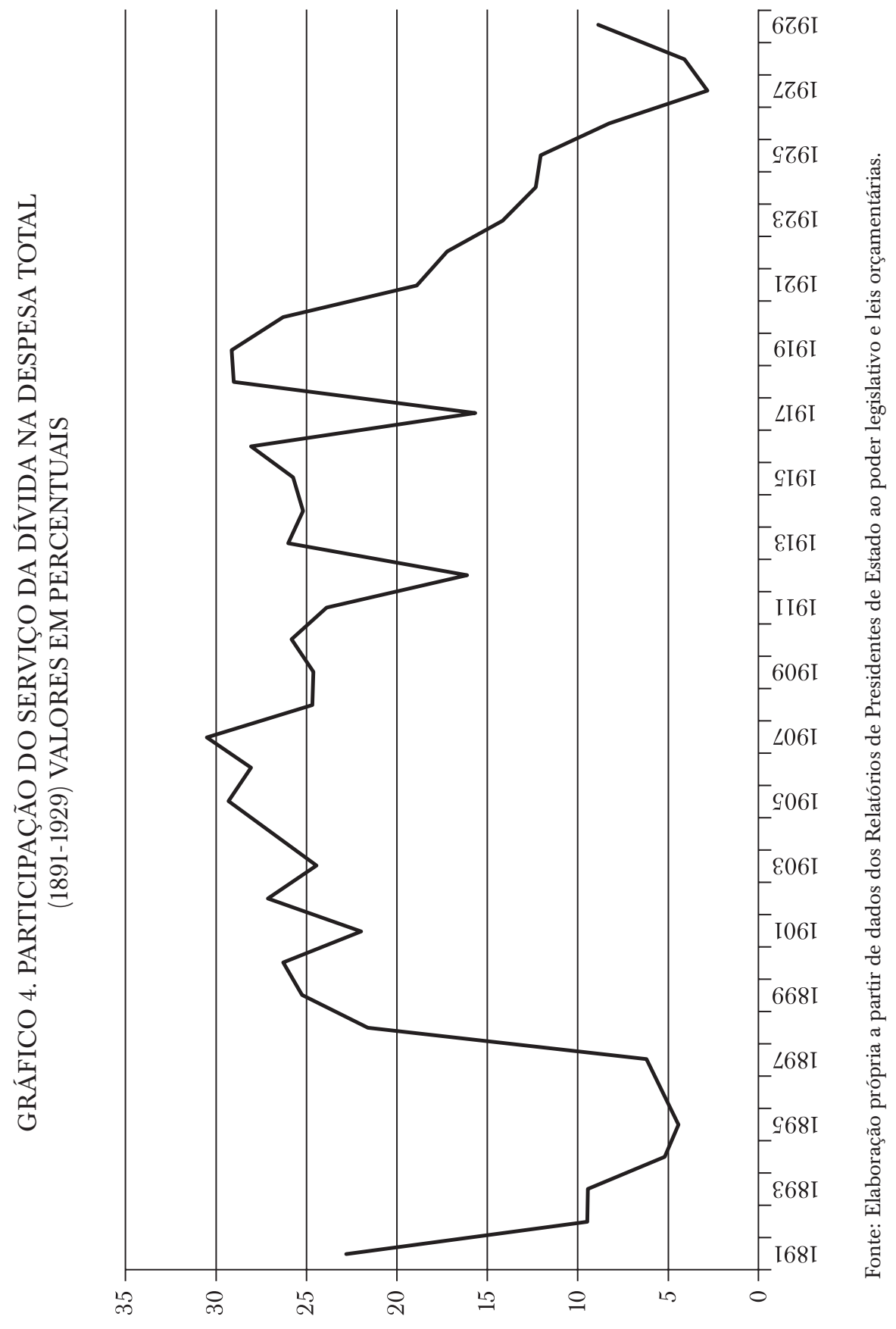


producção que o Estado recebe os maiores recursos para custear os serviços publicos, satisfazer seus compromissos e manter seu credito (Mensagem, 1904. pp. 10-11).

De qualquer modo, com o transcorrer dos anos, as políticas do governo voltadas para o desenvolvimento crescem relativamente à constante preocupação com o equilíbrio orçamentário. Em 1915, no Relatório do então presidente Delfim Moreira, asseverava-se a necessidade de medidas financeiras combinadas com a promoção do desenvolvimento como caminho para a solução da crise econômica do Estado:

Do que precisamos é de acção desassombrada, prompta e efficaz, sem mais discussões, para se afastar e se vencer a premencia do momento. A esse resultado só podemos chegar: $1^{\circ}$. Pelos grandes córtes nas despesas publicas; $2^{\circ}$. Pelo equilibrio effectivo e real dos orçamentos; $3^{\circ}$. Pelo desenvolvimento e expansão das fontes da producção e da receita; $4^{\circ}$. Pela rigorosa satisfação dos compromissos assumidos e conseguente elevação do credito publico (Mensagem, 1915. p. 10-11).

Segundo os dados recolhidos, há evidências que podem esclarecer sobre a mudança de atitude dos governantes mineiros com relação às políticas de desenvolvimento, ou sobre a tendência de crescente incorporação de prioridades de caráter desenvolvimentista. ${ }^{22}$ No período, a evolução do gasto em obras públicas -comumente concentradas em investimentos em infraestrutura- é indicador do lugar do desenvolvimento econômico nas políticas de governo. Como se afirmou, as leis orçamentárias indicam que os gastos em obras públicas foram pequenos na maior parte da República Velha, tendo correspondido, em média, a 7.3\% da despesa total anual estimada entre 1891 e 1929. Mesmo pelos Relatórios, é perceptível que a falta de recursos alocados na verba de obras públicas chamava a atenção dos presidentes. No Relatório de 1900, por exemplo, Silviano Brandão qualifica como "exígua" e "insuficiente" a verba para essa rubrica.

Pelo que se constata, os dados parecem corroborar as afirmações de Iglésias (1982), não fosse, ao menos, por mudança no final da Primeira República, quando entre 1923 e 1930 os gastos em obras públicas cresceram exponencialmente, tendo correspondido a uma média de $21.5 \%$ da despesa total anual estimada (ver gráfico 3.B).

A Diretoria de Viação, Obras Públicas e Indústria recebia verbas destinadas não só à rubrica de obras públicas, mas também às estradas de rodagem, estradas de ferro, navegação fluvial, entre outros. A Diretoria

${ }^{22}$ Políticas de corte desenvolvimentista em Minas Gerais na República Velha foram analisadas por diversos autores, com destaque para Paula (2004, pp. 273-281), Dulci (2005, pp. 114-133) e Barbosa (2012, pp. 72-106). 
nasceu como um dos dois órgãos resultantes da divisão da Diretoria Geral de Agricultura, Viação e Indústria, em 1907, e vinculou-se à Secretaria das Finanças até 1910, quando foi incorporada à recém-recriada Secretaria da Agricultura (Martins, 1995). Diferentemente do grupo de despesas obras públicas, a participação das despesas da Diretoria de Viação, Obras Públicas e Indústria nas despesas totais do Estado mostrou tendência ao crescimento a partir de, pelo menos, 1918, com grande salto entre 1922-1923 e entre 1926-1927. Os dados do gráfico 5 foram recolhidos em Relatório do Secretario da Agricultura, no final da década de 1920 (Minas Gerais, 1928).

Levando-se em conta que as verbas da Diretoria também eram destinadas para outras modalidades de dispêndios relacionados com políticas de promoção do desenvolvimento -portanto para além daquelas modalidades agrupadas como obras públicas-, a tendência mostrada pelo gráfico 5 sugere poder público cada vez mais disposto a aplicar seus recursos em fatores capazes de impulsionar o crescimento da economia estadual. Logo, embora a afirmativa de Iglésias (1982) pareça ser válida para a maior parte do período, muito provavelmente não se aplica à última década da República Velha.

Há ainda outros dados que podem oferecer interpretações não condizentes com a do eminente historiador. Como observado sobre o tabela 4 e o gráfico 4, o serviço da dívida correspondeu a mais de $20 \%$ da despesa orçamentária, para mais da metade do período, ou 21 anos dos 39 contemplados. Embora os Relatórios normalmente forneçam os valores da dívida externa do Estado somente em moeda estrangeira, sem nenhuma informação que permita compreender sua magnitude em moeda nacional, a quantidade de anos (frequentemente seguidos) em que a participação do serviço da dívida na despesa orçamentária atingiu níveis expressivos sugere que os empréstimos eram bastante elevados. Apesar dos compromissos assumidos serem constituídos por títulos a serem pagos no longo prazo, é de se surpreender que a dívida externa do ano de 1917 -única cujo valor os Relatórios definem em réis- seja quase 300\% maior que a despesa orçamentária total para aquele ano. Portanto, fato incompatível com Estado que tem "horror a empréstimos" (Iglésias, 1982, p. 132) ou que mantém uma preocupação especial com o equilíbrio orçamentário.

Embora a tomada de empréstimos elevados não indique, necessariamente, grande preocupação dos governantes com o desenvolvimento econômico (eles podem ter sido destinados para cobrir despesas correntes, por exemplo), ainda assim é muito improvável que o financiamento pelo Estado do processo de expansão ferroviária seja superado por outras destinações dadas aos recursos captados no exterior e que implicavam em forte endividamento (Barbosa, Godoy e Mendes, 2011, pp. 249-252). 


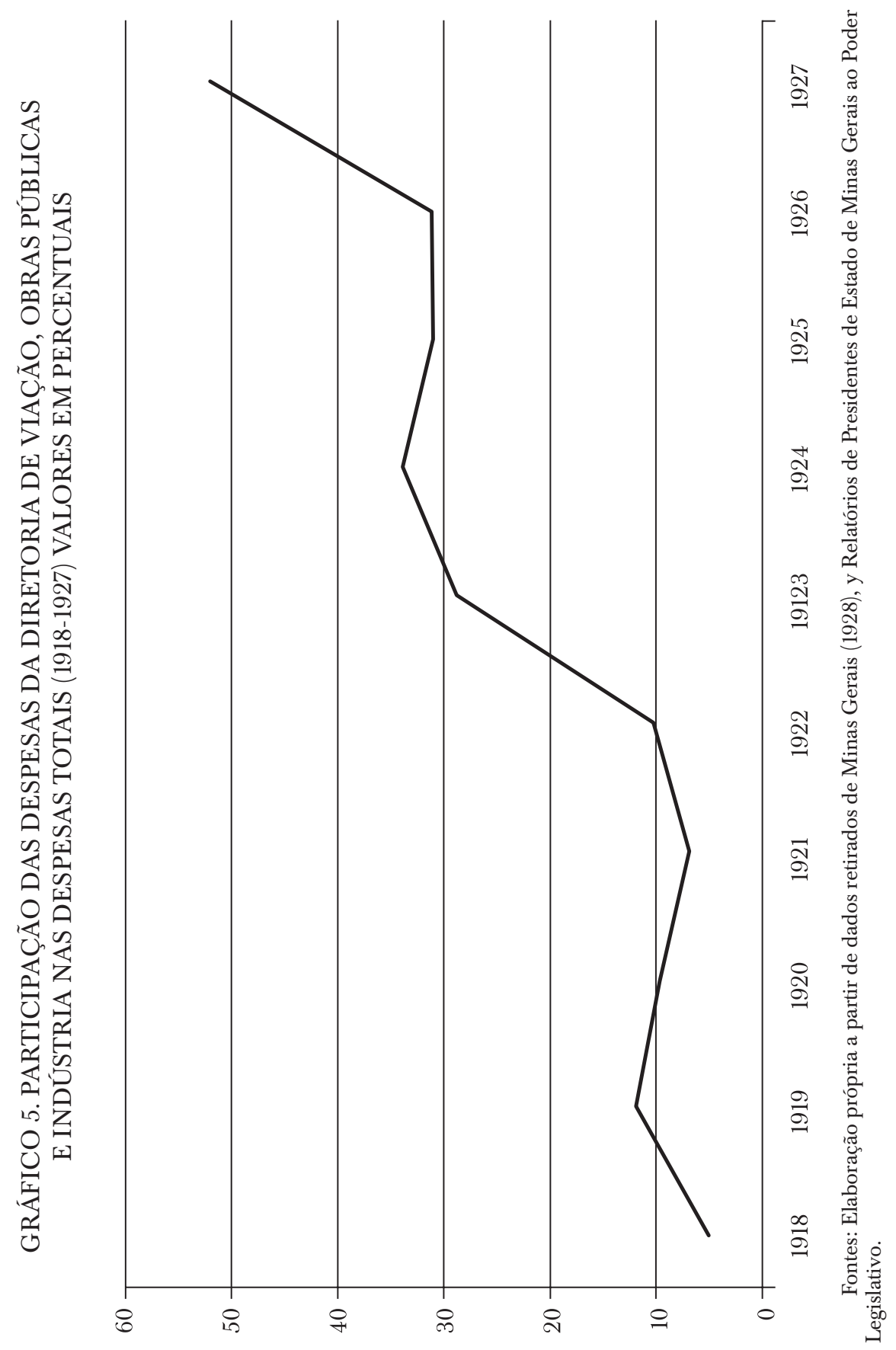




\section{Finanças públicas e os transportes em Minas Gerais na República Velha}

Os gráficos 6 e 6 .A permitem aferir o gasto do governo mineiro com estradas de ferro na primeira metade da República Velha, entre garantias de juros e subvenções, empréstimos e outras operações de crédito. Constata-se que o dispêndio destinado ao desenvolvimento da rede ferroviária foi bastante irregular, seja em termos nominais, seja em percentuais referentes à despesa total. A participação das despesas com estradas de ferro superou a $30 \%$ das despesas totais em 1896, ultrapassou a $20 \%$ em outros três anos e manteve-se em patamar bem menos expressivo no restante do período. Outrossim, observa-se tendência mais duradoura à redução desses gastos a partir de 1907, com a participação nos gastos totais se tornando nula entre 1911 e 1915.

Embora não localizados dados referentes aos anos de 1916 e 1917, o dispêndio com ferrovias em 1918 também foi nulo, o que permite supor que é pouco provável que o quadro tenha se alterado entre 1911 e 1918. O gráfico 6.B, para o período 1918 a 1927, evidencia pronunciada elevação das despesas com estradas de ferro a partir de 1919 (considerados gastos com construção, conservação, fiscalização e subvenções). As despesas com o setor ferroviário corresponderam a mais de $50 \%$ da despesa total da Diretoria de Obras Públicas, Viação e Indústria, tendo inclusive atingido participação bem próxima dos 80\% em 1924. A maior parte desses gastos destinou-se a E. F. Paracatu e à Rede Sul-Mineira. Ao forte crescimento dos valores da despesa total anual do Estado de Minas Gerais ao longo do período, correspondeu tendência ainda mais acentuada, no mesmo sentido, do valor nominal dos gastos com estradas de ferro. Se, em 1919, o dispêndio com ferrovias correspondia a $7.6 \%$ das despesas totais do governo, em 1927 alcançava 36.2 por cento.

Em síntese, pode-se afirmar que, mesmo após a forte aceleração do crescimento de investimentos em estradas de rodagem no fim da Primeira República, que será discutida na sequência, o interesse do Estado pela modal ferroviária jamais arrefeceu. Desde o início da aceleração da expansão dos trilhos, nas últimas décadas do império, e mesmo considerados os períodos lacunares (sem dados) ou contrastantes (com dados que descontinuam tendências anteriores), parecem inequívocas as evidências que sustentam a permanência de eixo seguro a estabelecer vinculação estreita entre o Estado e a modernização ferroviária, por meio de poderosos subsídios aos investimentos na construção e operação das estradas de ferro (Batista, Barbosa e Godoy, 2012, pp. 171-180). Eixo corroborado pela curva de crescimento da malha ferroviária na República Velha, segundo o gráfico 6.C, que representa a evolução da quilometragem dos trilhos de Minas Gerais entre 1893 e 1928 (Jacob, 1911, pp. 441-448 e Relatórios de 


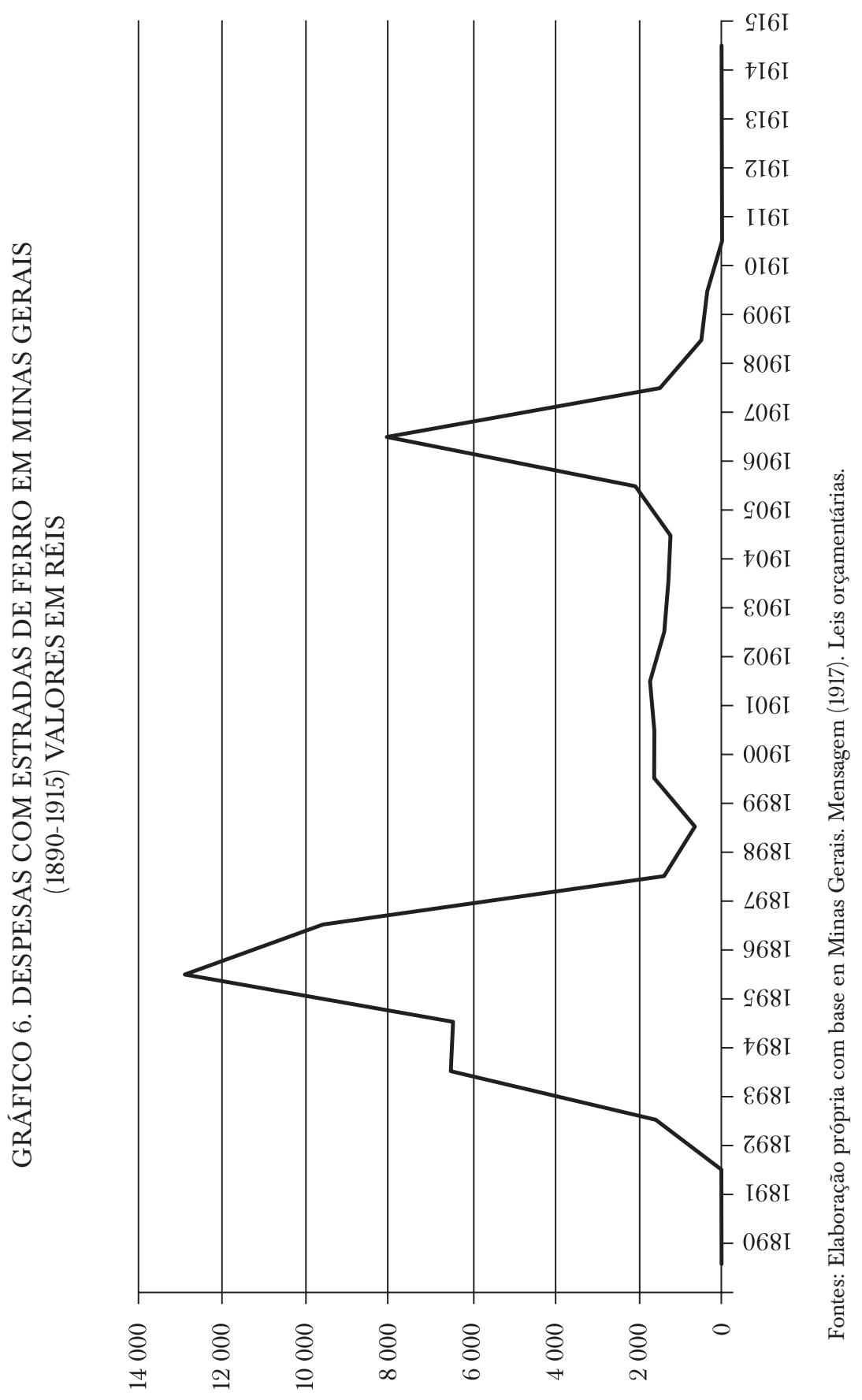




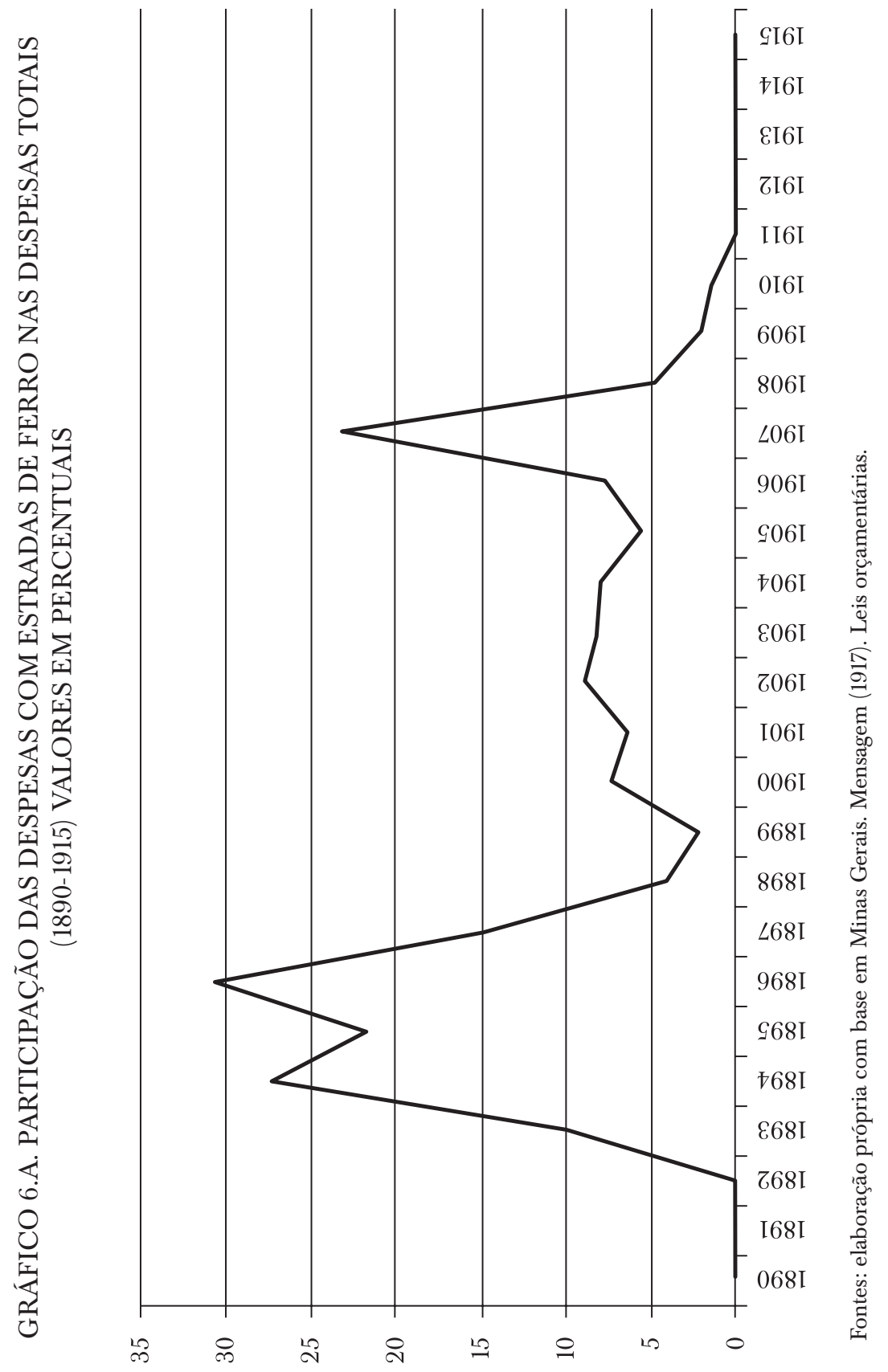




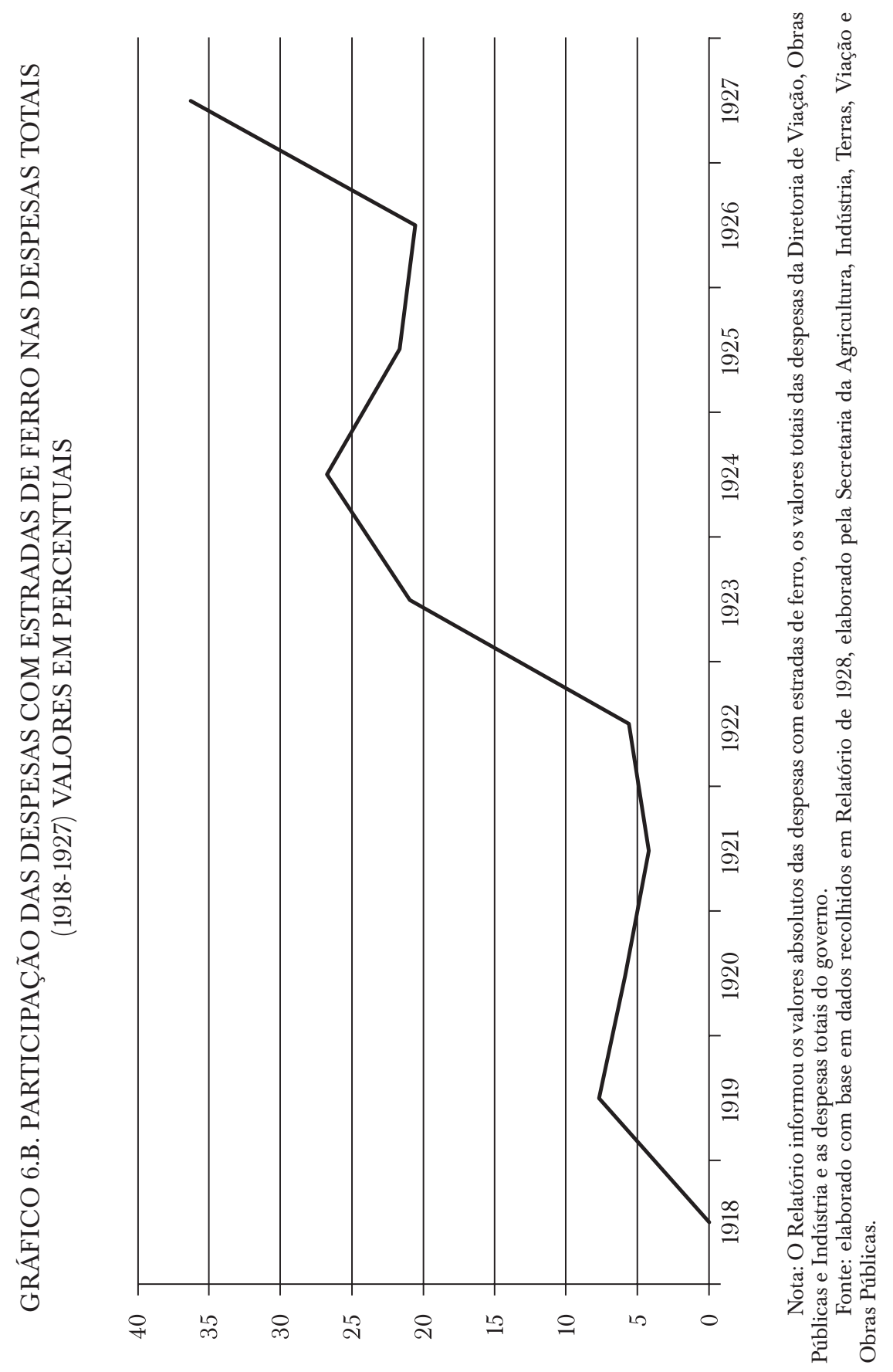


Presidentes de Estado). O crescimento em termos absoluto das despesas, para os períodos contemplados pelos dados recolhidos, não está espelhado no ritmo de crescimento da malha ferroviária. $\mathrm{O}$ valor do coeficiente de determinação $\left(\mathrm{R}^{2}\right)$ da amostra, que mede o quanto os dados empíricos se aproximam de uma regressão linear estimada a partir dos mesmos, é de 0.9653. Como se considera que um modelo é mais bem ajustado a uma amostra quanto mais próximo esse índice estiver da unidade, conclui-se que o ritmo de crescimento da extensão dos trilhos foi quase constante no período. A vigorosa elevação da despesa em termos absolutos entre 1918 e 1927 encontraria explicação na expansão do dispêndio público com ferrovias encampadas, deficitárias e com operação subsidiada pelo Estado, em especial a Rede Mineira de Aviação, bem como no pagamento de garantias sobre investimentos e operação de empresas privadas (Batista, Barbosa e Godoy, 2012, pp. 171-180).

É visível o crescimento da preocupação dos governantes mineiros com as estradas de rodagem no transcurso da República Velha. São raríssimas as menções a esse modal de transporte nos primeiros Relatórios de Presidentes de Estado. Entretanto, gradualmente, as estradas de rodagem começaram a constar nas partes dos Relatórios que versavam sobre obras públicas, para, na segunda metade da Primeira República, ganharem espaço considerável.

Os dados relativos às despesas com estradas de rodagem espelham bem a elevação do interesse gerado por essa modalidade de transporte, como demonstram os gráficos 7 e 7.A (Minas Gerais, 1928). Vê-se que os gastos em estradas corresponderam, inicialmente, a uma parcela ínfima da despesa total. Com o transcorrer dos anos, essa parcela mostrou tendência ao crescimento, ainda que a um ritmo lento. A partir de 1923, porém, essas despesas começaram a se elevar aceleradamente, chegando a equivaler a 10\% da despesa total em 1929.

A participação das despesas com estradas de rodagem no gasto da Diretoria de Viação, Obras Públicas e Indústria foi bastante irregular, tendo atingido valores tão altos quanto $36 \%$, em 1918, e tão baixos quanto $3.6 \%$, em 1923 (Minas Gerais, 1928) (ver tabela 5).

A extensão das rodovias construídas (estradas ou trechos de estradas novos) e, principalmente, sob manutenção (estradas ou trechos de estradas retificados ou reabertos à circulação) do governo do Estado de Minas Gerais cresceu bastante após a criação em 1923 da Inspetoria de Estradas de Rodagem, tendo passado de 6471.9 quilômetros, no primeiro semestre de 1925, para 18408.9 quilômetros, em 1929, resultando em uma média de 1326 quilômetros por semestre. No entanto, a maior parte dessa expansão estava ao encargo dos municípios, sem subvenções fornecidas pelo Estado (Mattos, 1932, p. 49). Entre 1927 e 1931, os municípios mineiros desti- 


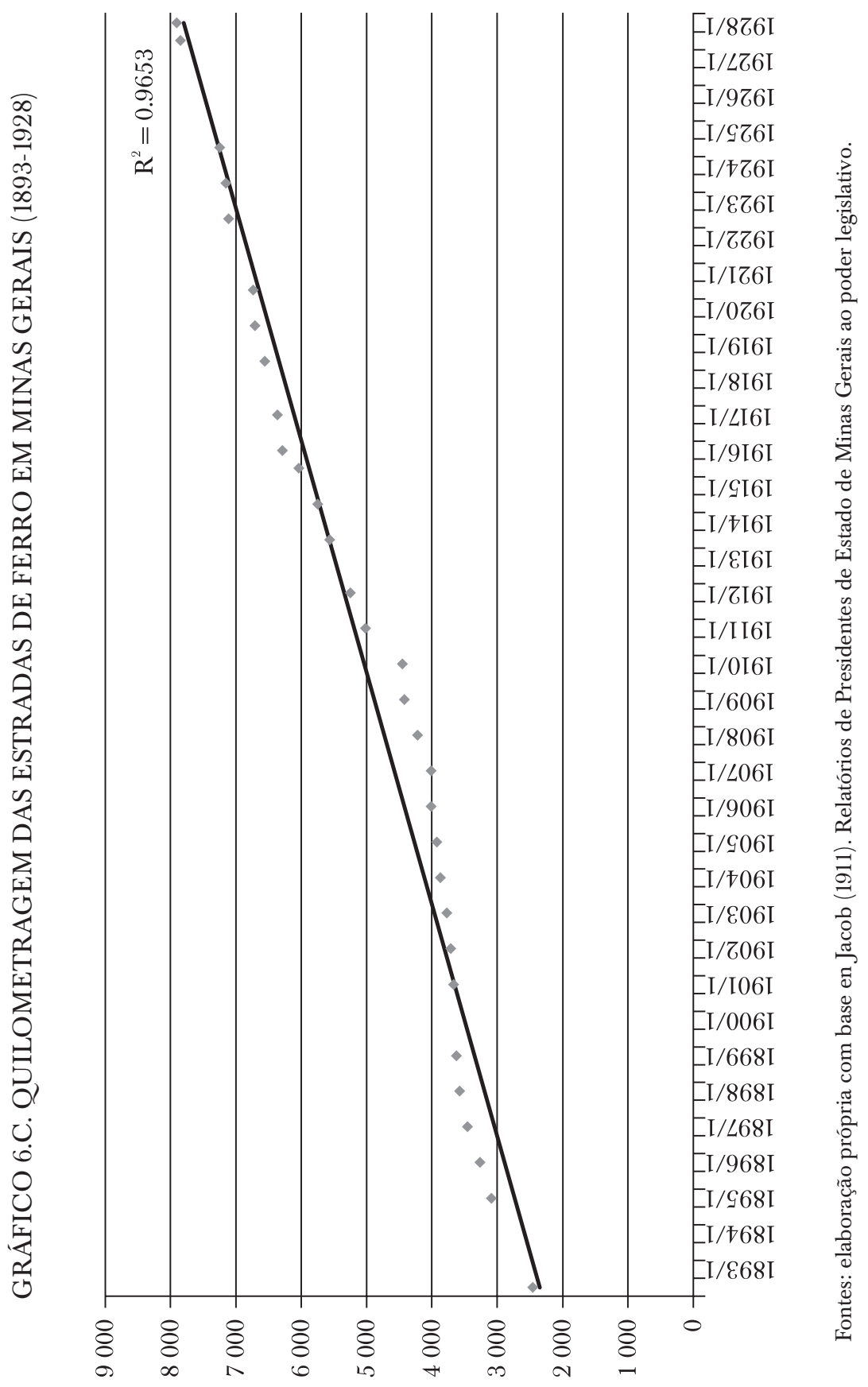




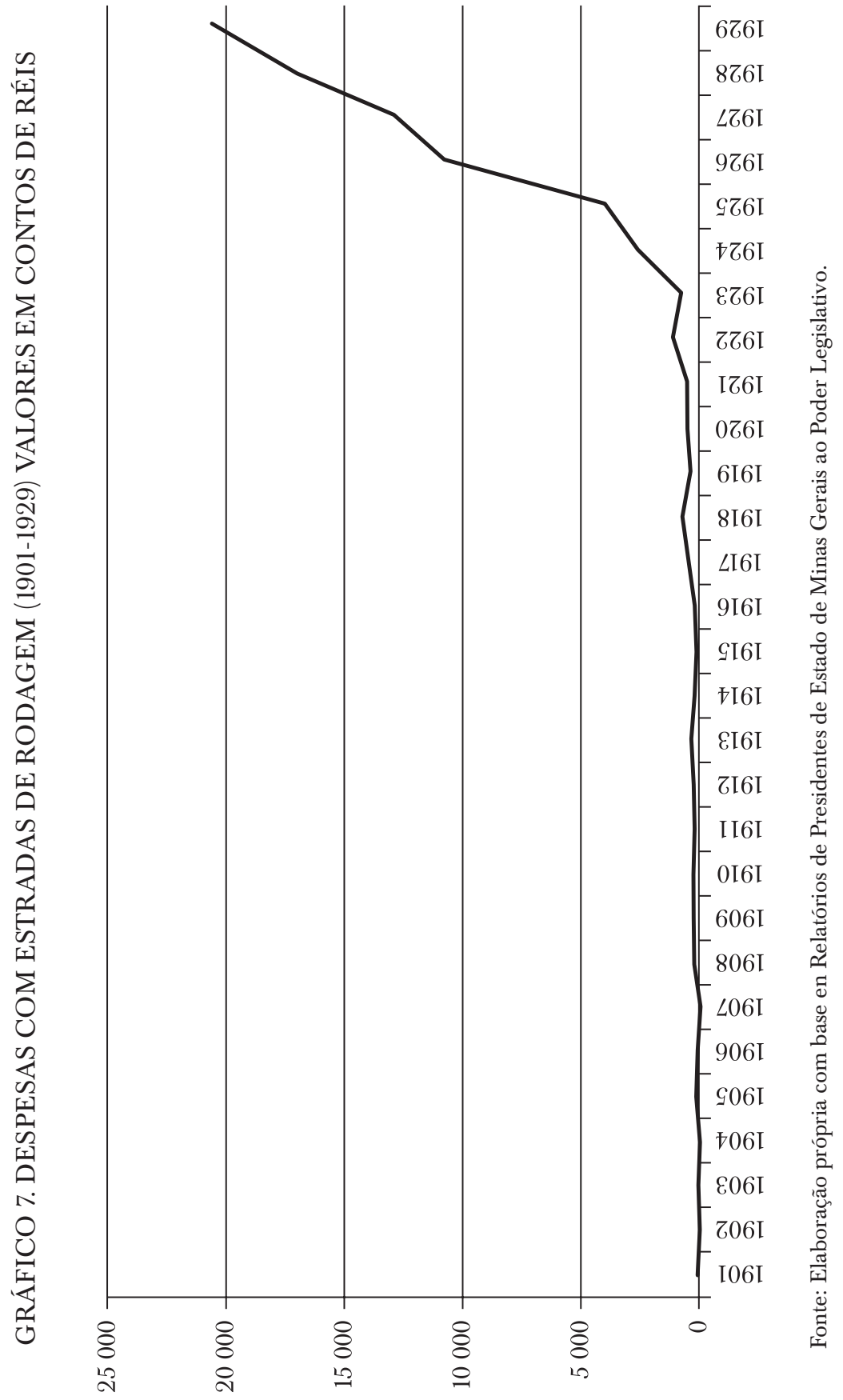




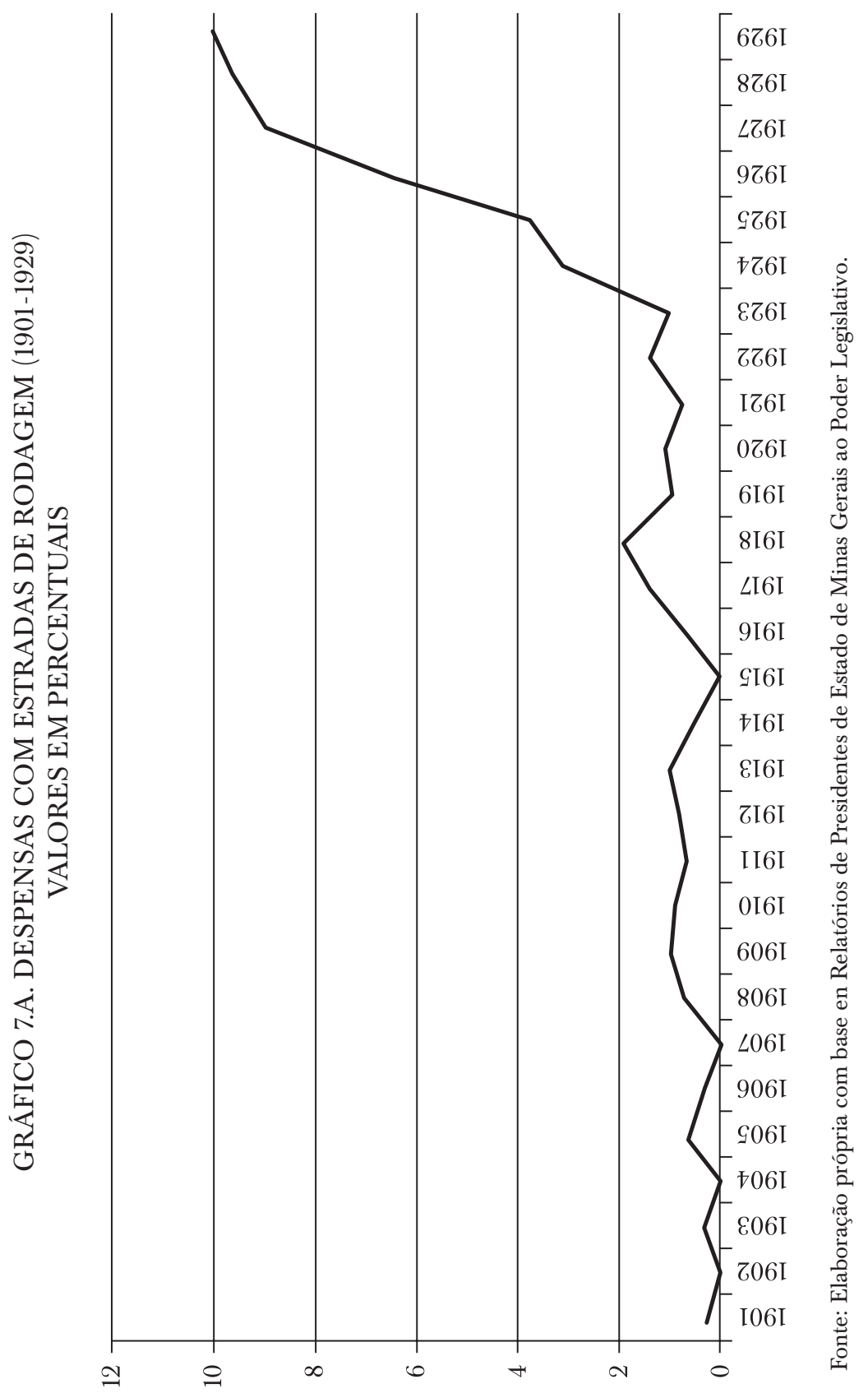


Am. Lat. Hist. Econ., año 24, núm. 2, mayo-agosto, 2017, pp. 148-200

TABELA 5. PARTICIPAÇÃO RELATIVA DAS DESPESAS COM ESTRADAS DE RODAGEM NA VERBA DA DIRETORIA DE VIAÇÃO, OBRAS PÚBLICAS E INDÚSTRIAS

\begin{tabular}{lccc}
\hline Ano & Porcentagem & Ano & Porcentagem \\
& & & \\
1918 & 36.04 & 1923 & 3.59 \\
1919 & 8.13 & 1924 & 9.11 \\
1920 & 11.30 & 1925 & 12.00 \\
1921 & 11.11 & 1926 & 21.37 \\
1922 & 13.52 & 1927 & 17.32 \\
\hline
\end{tabular}

Fonte: Minas Gerais (1928).

naram, em média, $33.2 \%$ dos seus gastos com a rubrica obras públicas, estradas e pontes (Minas Gerais, 1937, p. 277).

Consideradas apenas as estradas subvencionadas, verificou-se salto de 1954.3 quilômetros de estradas em Minas Gerais, segundo balanço do primeiro semestre de 1925, para 4643.4 quilômetros de estradas subvencionadas no estado, segundo o balanço do segundo semestre de 1929, o que resulta em uma média de quase $299 \mathrm{~km}$ implantados por semestre. Já as estradas não subvencionadas, de 4193.7 quilômetros, segundo balanço do primeiro semestre de 1925, alcançaram 13765.5 quilômetros, segundo o balanço do segundo semestre de 1929. A evolução da quilometragem das estradas de rodagem em Minas Gerais está representada no gráfico 7.B, segundo dados recolhidos nos Relatórios de Presidentes de Estado.

\section{SÍNTESE}

Em Minas Gerais, na República Velha, o governo dividia tanto a receita quanto a despesa em ordinárias e extraordinárias. Aparentemente, as despesas ordinárias eram as primeiras a serem estimadas, seguidas das receitas ordinárias, sempre com base no passado recente. Os desequilíbrios seriam compensados com receitas extraordinárias, que, por sua vez, serviriam de base para a estimação das despesas extraordinárias.

Tanto os valores nominais da receita quanto os da despesa apresentaram tendência contínua de elevação ao longo da República Velha, muito provavelmente mais impulsionados pelo crescimento econômico do que pela inflação do período. Prevalecia significativa distância entre as receitas e despesas orçadas e as executadas. Embora estas tendências vigorassem 


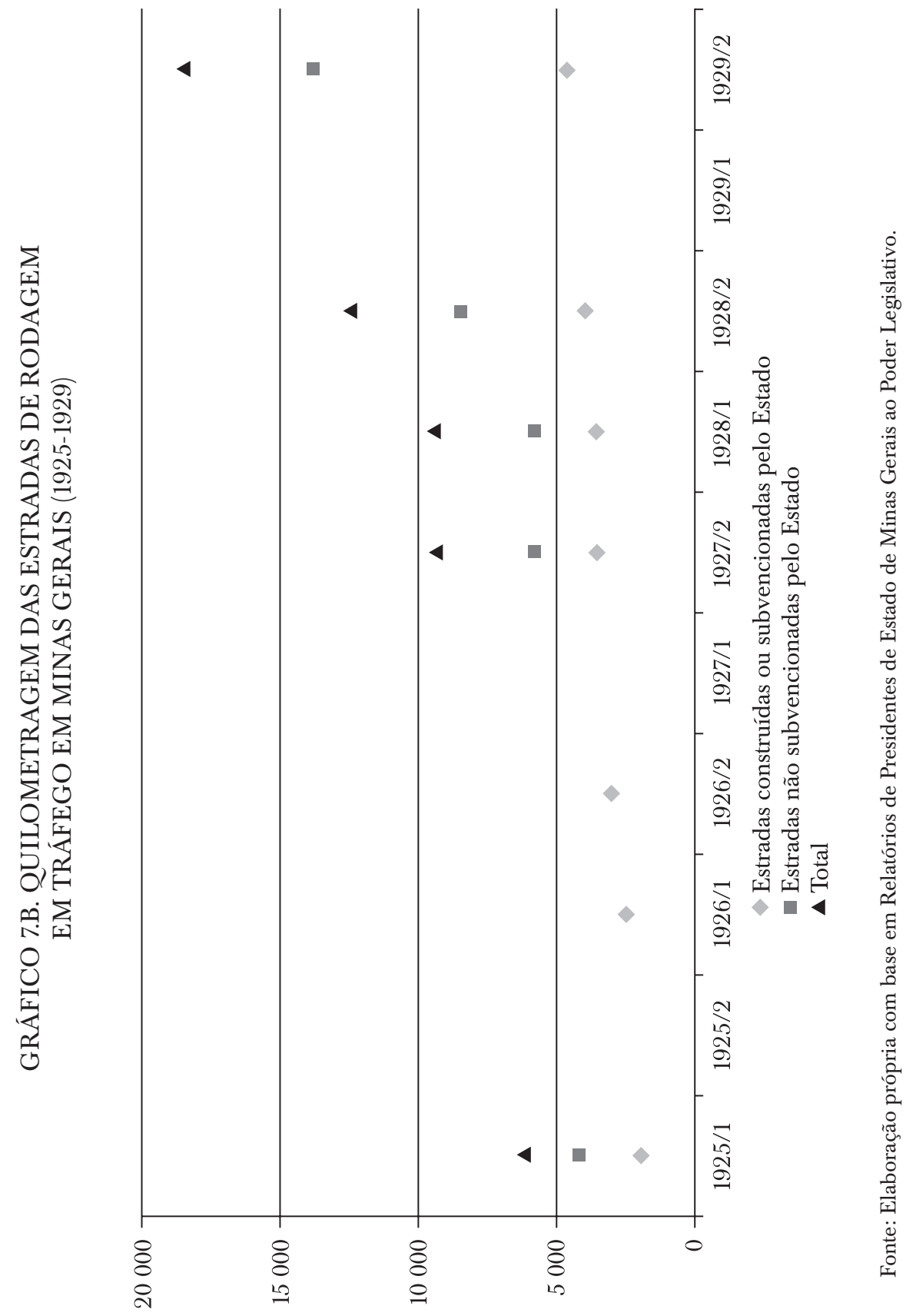


também no período imperial, é notável que a tendência das despesas orçadas superarem as receitas, marcante no império, tenha se invertido na Primeira República, inclusive na execução orçamentária.

Nas receitas, a predominância era da receita ordinária, e, em sua composição, a receita tributária era a de maior importância. A maior parte da arrecadação tributária originava-se da cobrança de impostos, cabendo às taxas um papel menor. O imposto mais importante ao longo de todo o período foi o de exportação, ainda que sua participação na receita total tenha diminuído no transcurso da República Velha em benefício de outras rubricas. Outrossim, a receita como um todo se desconcentrou progressivamente e reduziu sua dependência em relação ao comércio externo, com os números arrecadados se tornando mais isonomicamente distribuídos entre as fontes. Sendo a arrecadação ancorada na tributação de produtos primários (agropecuários), estava sujeita a variações. Assim, para tornar a receita equiparável à despesa, que tendia a ser mais linear, era ocasionalmente necessário recorrer a operações de crédito.

Quanto às despesas, observou-se que se destacavam os gastos com segurança pública e, especialmente, com educação. Nem as despesas com saúde e assistência, bem como com obras públicas, eram expressivas. Os gastos com a administração superior, apesar de irregulares, apresentaram leve tendência declinante em termos de participação relativa. O serviço da dívida (tanto a dívida fundada, quanto as operações de crédito por antecipação de receita) correspondeu a um alto percentual da despesa em diversos anos.

O gasto com estradas de ferro, pelo menos em termos de operações de crédito, parece irregular até pouco depois da metade da Primeira República, ainda que tenha se configurado uma tendência declinante a partir de 1907. De 1919 em diante, porém, é perceptível a tendência ascendente das despesas com ferrovias, que ultrapassaram 35\% da despesa total em 1927. Ainda assim, esse aumento de despesas não parece ter influenciado o ritmo de crescimento das estradas de ferro, que permaneceu praticamente o mesmo ao longo de todo o período em estudo.

As despesas com estradas de rodagem foram baixas na maior parte da República Velha, embora tenham passado por lento crescimento até 1923, ano de criação da Inspetoria de Estradas de Rodagem. Desde então, o crescimento das despesas nessa área foi vertiginoso, tendo correspondido a 10\% da despesa total em 1929 (no período anterior a 1923, jamais havia chegado aos 2\%). Diferentemente das estradas de ferro, a elevação das despesas foi acompanhada por forte crescimento da extensão das estradas de rodagem mineiras. Embora a maior parte dessa expansão tenha ocorrido pelas mãos dos governos municipais, o crescimento das estradas subvencionadas pelo governo do Estado pode ser considerado expressivo. 


\section{LISTA DE REFERÊNCIAS}

Abreu, M. D. P. (1999). Brasil, 1824-1957: bom ou mau pagador? (Texto para discussão). Rio de Janeiro: Pontifícia Universidade Católica do Rio de Janeiro.

ACIOLI, R. (2007). Os mecanismos de financiamento das ferrovias brasileiras (Dissertação de mestrado). Universidade Federal do Rio de Janeiro, Brasil.

Barbosa, D. H. (2012). Tecnoburocracia e pensamento desenvolvimentista em Minas Gerais (1903-1969) (Tese de doutorado). Universidade de São Paulo, Brasil.

Barbosa, L. S., Godoy, M., Mendes, Ph. Sh. (2011). Transportes e finanças públicas: contribuição para o estudo do lugar do dispêndio em infraestrutura viária nos orçamentos provinciais e municipais de Minas Gerais, 1835-1889. Em A. GoularTi e P. R. C. QUEIROZ (orgs.), Transportes e formação regional: contribuição à história dos transportes no Brasil. Dourados: Universidade Federal da Grande Dourados.

Bastos, C. D. A. (1997). Instituições financeiras de Minas Gerais, 1819-1995. Belo Horizonte: s. e.

Batista, F., Barbosa, L. S., Godoy, M. (2012). Transportes, modernização e formação regional: Subsídios à história da era ferroviária em Minas Gerais, 1870-1940. Revista de História Regional, 17(1), 162-203.

Bessa, A. L. D. (1981). História financeira de Minas Gerais em 70 anos de República. Belo Horizonte: Imprensa Oficial.

Calógeras, J. P. (1931). Reforma tributária de Minas. Belo Horizonte: Imprensa Oficial.

Costa, F. e Deos, S. (2002). Reflexões sobre o financiamento na economia brasileira. Análise Econômica, 19(36), 23-44.

Costa, W. (1998). A questão fiscal na transformação republicana - continuidade e descontinuidade. Economia e Sociedade, 10, 141-173.

Dulci, O. (1999). Política e recuperação econômica em Minas Gerais. Belo Horizonte: Universidade Federal de Minas Gerais.

Dulci, O. (2005). João Pinheiro e as origens do desenvolvimento mineiro. Em: GoMes, Ângela de Castro (org.). Minas e os fundamentos do Brasil moderno. Belo Horizonte: Universidade Federal de Minas Gerais.

Ferreira, M. D. M. e Pinto, S. C. S. (2003). A crise dos anos 1920 e a revolução de 1930. Em J. Ferreira e L. A. Delgado, O tempo do liberalismo excludente. Rio de Janeiro: Civilização Brasileira.

FundaÇão João Pinheiro (2006). Memória política de Minas Gerais: Raul Soares de Moura. Belo Horizonte: Autor/Centro de Estudos Históricos e Culturais.

Furtado, C. (1959). Formação econômica do Brasil. Rio de Janeiro: Editora Fundo de Cultura.

IGLÉsIAS, F. (1982). Política econômica do estado de Minas Gerais, 1890-1930. Em N. D. G. Monteiro (org.). Seminário de estudos mineiros: a República Velha em Minas. Belo Horizonte: Universidade Federal de Minas Gerais. 
Instituto Brasileiro de GeOgrafia e Estatística [IBGE] (1941). Repertório Estatístico do Brasil, Quadros Retrospectivos $n^{0} 1$ (Separata do Anuário Estatístico do Brasil, ano V, 1939-1940). Rio de Janeiro: Autor.

JaCOb, R. (1911). Minas Gerais no XX seculo. Rio de Janeiro: Gomes, Irmão \& C.

Lopreato, F. L. C. (2002). O colapso das finanças e a crise da federação. São Paulo: Universidad Estatal Paulista.

MAia, J. N. e SARAiva, J. F. (2012). A paradiplomacia financeira no Brasil da República Velha, 1890-1930. Revista Brasileira de Politica Internacional, 55(1), 106-134.

Martins Filho, A. V. (2009). O segredo de Minas: a origem do estilo mineiro de fazer política (1889-1930). Belo Horizonte: Crisálida.

Martins, M. D. C. (1995). Estrutura e dinâmica da organização político-administrativa de Minas Gerais. Belo Horizonte: Arquivo Público Mineiro.

Mattos, S. D. (1932). O problema das estradas de rodagem. Belo Horizonte: Imprensa Oficial.

Mendes, Ph. Sh. (2007). Finanças públicas da província de Minas Gerais. Belo Horizonte: Universidade Federal de Minas Gerais.

Minas Gerais (1928). Secretaria de Estado da Agricultura. Relatorio apresentado ao Sr. Dr. Antonio Carlos Ribeiro de Andrada, Presidente do Estado de Minas Gerais, pelo Sr. Dr. Djalma Pinheiro Chagas, Secretario da Agricultura, Industria, Terras, Viação e Obras Publicas, e referente ao periodo de $1^{\circ}$ de janeiro de 1927 a 15 de junho de 1928. Belo Horizonte: Imprensa Oficial do Estado de Minas Gerais.

Minas Gerais (1937). Finanças municipaes no Estado de Minas Gerais (1927-1931). Belo Horizonte: Officinas Graphicas da Estatistica.

Minas Gerais (1954). Finanças do Estado de Minas Gerais: período republicano, 1890-1953. Belo Horizonte: Secretaria das Finanças.

Minas Gerais (1981). Congresso Agrícola, Industrial e Comercial de 1903. Fundação João Pinheiro, 1(5-6), 122-220. Belo Horizonte: Fundação João Pinheiro.

Ónody, O. (1960). A inflação brasileira (1820-1958). Rio de Janeiro: s. e.

Paula, J. A. D. (2004). Raízes do desenvolvimentismo: pensamento e ação de João Pinheiro. Pesquisa \& Debate. Revista do Programa de Estudos Pós-Graduados em Economia Política, 15(2(26)), 257-282.

Prado, C. (1959). História Econômica do Brasil. São Paulo: Brasiliense.

Resende, M. E. L. D. (2003). O processo político na Primeira República e o liberalismo oligárquico. Em J. Ferreira e L. D. A. N. Delgado, O tempo do liberalismo excludente: da Proclamação da República à Revolução de 1930. Rio de Janeiro: Civilização Brasileira.

TARga, L. R. P. (2008). A política fiscal modernizadora do Partido Republicano Riograndense na Primeira República (1889-1930) (Textos para discussão FEE, 26). Porto Alegre: Fundação de Economia e Estatística Siegfried Emanuel Heuser.

WiRTH, J. D. (1982). O fiel da balança: Minas Gerais na federação brasileira, 1889-1937. Rio de Janeiro: Paz e Terra. 


\section{Fontes primárias}

Colleçã̃o das leis e decretos do Estado de Minas Gerais: orçamentos da receita e despesa do Estado de Minas Gerais (1890-1929). Ouro Preto-Belo Horizonte: Imprensa Official do Estado de Minas Gerais, vários anos.

Mensajem dirigida pelo presidente do Estado Dr. Delfim Moreira da Costa Ribeiro ao Congresso Mineiro em sua $7^{a}$ Sessão Ordinaria da $7^{a}$ Legislatura no anno de 1915 (1915). Bello Horizonte: Imprensa Official do Estado de Minas Gerais.

Mensajem dirigida pelo pesidente do Estado Dr. Francisco Antonio de Salles ao Congresso Mineiro em Sessão Extraordinaria da $4^{a}$ Legislatura no anno de 1904. (1904). Bello Horizonte: Imprensa Official do Estado de Minas Gerais.

Mensagens apresentadas pelos (vice) presidentes do Estado de Minas Gerais ao Congresso Mineiro, 1891-1930 (varios años). Ouro Preto-Belo Horizonte: Imprensa Official do Estado de Minas Gerais. Recuperado de www.crl.edu

Mensajem dirigida pelo Vice-Presidente do Estado Dr. Joaquim Candido da Costa Sena ao Congresso Mineiro, em sua quarta sessão ordinaria da terceira legislatura no ano de 1902 (1902). Bello Horizonte: Imprensa Official do Estado de Minas Gerais.

Mensagem do Exmo Sr. Presidente do Estado apresentando a proposta do orçamento para 1918: acompanhada de dados referentes à receita, à despesa e aos compromissos do Estado de 1888 a 1915 e do balanço de 1916 (1917). Belo Horizonte: Imprensa Official do Estado de Minas Gerais. 